\title{
Stimulation of poliovirus RNA synthesis and virus maturation in a HeLa cell-free in vitro translation-RNA replication system by viral protein 3CDpro
}

\author{
David Franco ${ }^{1}$, Harsh B Pathak ${ }^{2}$, Craig E Cameron ${ }^{2}$, Bart Rombaut ${ }^{3}$, \\ Eckard Wimmer ${ }^{1}$ and Aniko V Paul*1
}

Address: ${ }^{1}$ Department of Molecular Genetics and Microbiology, School of Medicine, Stony Brook University, Stony Brook, N. Y. 11790, USA, ${ }^{2}$ Department of Biochemistry and Molecular Biology, Pennsylvania State University, University Park, Pennsylvania 16802, USA and ${ }^{3}$ Department of Microbiology and Hygiene, Vrije Universiteit Brussel, B-1090 Brussels, Belgium

Email: David Franco - davidfranco72@yahoo.com; Harsh B Pathak - hxp141@psu.edu; Craig E Cameron - cec9@psu.edu; Bart Rombaut - brombaut@vub.ac.be; Eckard Wimmer - ewimmer!@ms.cc.sunysb.edu; Aniko V Paul* - apaul@notes.cc.sunysb.edu

* Corresponding author

Published: 21 November 2005

Virology Journal 2005, 2:86 doi:10.1 186/1743-422X-2-86

This article is available from: http://www.virologyj.com/content/2/I/86

(c) 2005 Franco et al; licensee BioMed Central Ltd.

This is an Open Access article distributed under the terms of the Creative Commons Attribution License (http://creativecommons.org/licenses/by/2.0), which permits unrestricted use, distribution, and reproduction in any medium, provided the original work is properly cited.
Received: 30 June 2005

Accepted: 2I November 2005

\begin{abstract}
Poliovirus protein 3 CDpro possesses both proteinase and RNA binding activities, which are located in the 3 Cpro domain of the protein. The RNA polymerase (3Dpol) domain of 3 CDpro modulates these activities of the protein. We have recently shown that the level of 3CDpro in HeLa cell-free in vitro translation-RNA replication reactions is suboptimal for efficient virus production. However, the addition of either $3 C D$ pro mRNA or of purified $3 C D$ pro protein to in vitro reactions, programmed with viral RNA, results in a 100 -fold increase in virus yield. Mutational analyses of $3 C D$ pro indicated that RNA binding by the 3 Cpro domain and the integrity of interface $I$ in the 3Dpol domain of the protein are both required for function. The aim of these studies was to determine the exact step or steps at which 3 CDpro enhances virus yield and to determine the mechanism by which this occurs. Our results suggest that the addition of extra 3CDpro to in vitro translation RNA-replication reactions results in a mild enhancement of both minus and plus strand RNA synthesis. By examining the viral particles formed in the in vitro reactions on sucrose gradients we determined that $3 C D$ pro has only a slight stimulating effect on the synthesis of capsid precursors but it strikingly enhances the maturation of virus particles. Both the stimulation of RNA synthesis and the maturation of the virus particles are dependent on the presence of an intact RNA binding site within the 3 Cpro domain of $3 C D$ pro. In addition, the integrity of interface $I$ in the 3Dpol domain of $3 C D$ pro is required for efficient production of mature virus. Surprisingly, plus strand RNA synthesis and virus production in in vitro reactions, programmed with full-length transcript RNA, are not enhanced by the addition of extra $3 C D$ pro. Our results indicate that the stimulation of RNA synthesis and virus maturation by $3 \mathrm{CD}$ pro in vitro is dependent on the presence of a VPg-linked RNA template.
\end{abstract}




\section{Introduction}

The HeLa cell-free in vitro translation-RNA replication system [1] offers a novel and useful method for studies of the individual steps in the life cycle of poliovirus. These processes include the translation of the input RNA, processing of the polyprotein, formation of membranous replication complexes, uridylylation of the terminal protein $\mathrm{VPg}$, synthesis of minus and plus strand RNA, and encapsidation of the progeny RNA genomes to yield authentic progeny virions [1-4]. Although these processes occurring in vitro represent, in large part, what happens in virus-infected cells, there are also differences between virus production in vivo and in vitro. In the in vitro system a large amount of viral RNA ( $1 \times 10^{11}$ RNA molecules) has to be used, as template for translation and replication, in order to obtain infectious viral particles and the yield of virus is still relatively low. This has been attributed to insufficient concentrations of viral proteins for RNA synthesis or encapsidation, to differences in membranous structures or the instability of viral particles in vitro $[3,5]$. With the large amount of input RNA the level of translation in vitro is relatively high from the beginning of incubation and hence complementation between viral proteins is more efficient than in vivo [6,7]. We have recently observed that in vitro translation-RNA replication reactions, programmed with viral RNA, contain subopti- mal concentrations of the important viral precursor protein 3CDpro for efficient virus production. By supplying the in vitro reactions at the beginning of incubation either with $3 C^{\text {pro }}$ mRNA or purified 3CDpro protein the virus yield could be enhanced 100 fold $[8,9]$. Our results also indicated that both the 3Cpro proteinase and 3Dpol polymerase domains of the protein are required for its enhancing activity.

Poliovirus (PV), a member of the Picornaviridae virus family, replicates its plus strand genomic RNA within replication complexes contained in the cytoplasm of the infected cell. These complexes provide a suitable environment for increased local concentration of all the viral and cellular proteins needed for RNA replication and encapsidation of the progeny RNA genomes. Translation of the incoming plus strand RNA genome of PV yields a polyprotein, which is cleaved into functional precursors and mature structural and nonstructural proteins (Fig. 1). This is followed by the synthesis of a complementary minus strand RNA, which is used as template for the production of the progeny plus strands [reviewed in [10]]. Although the process of viral particle assembly is not fully understood it is believed to occur by the following pathway: The P1 precursor of the structural proteins is cleaved into VP0, VP1 and VP3, which form a noncovalent complex, the pro-

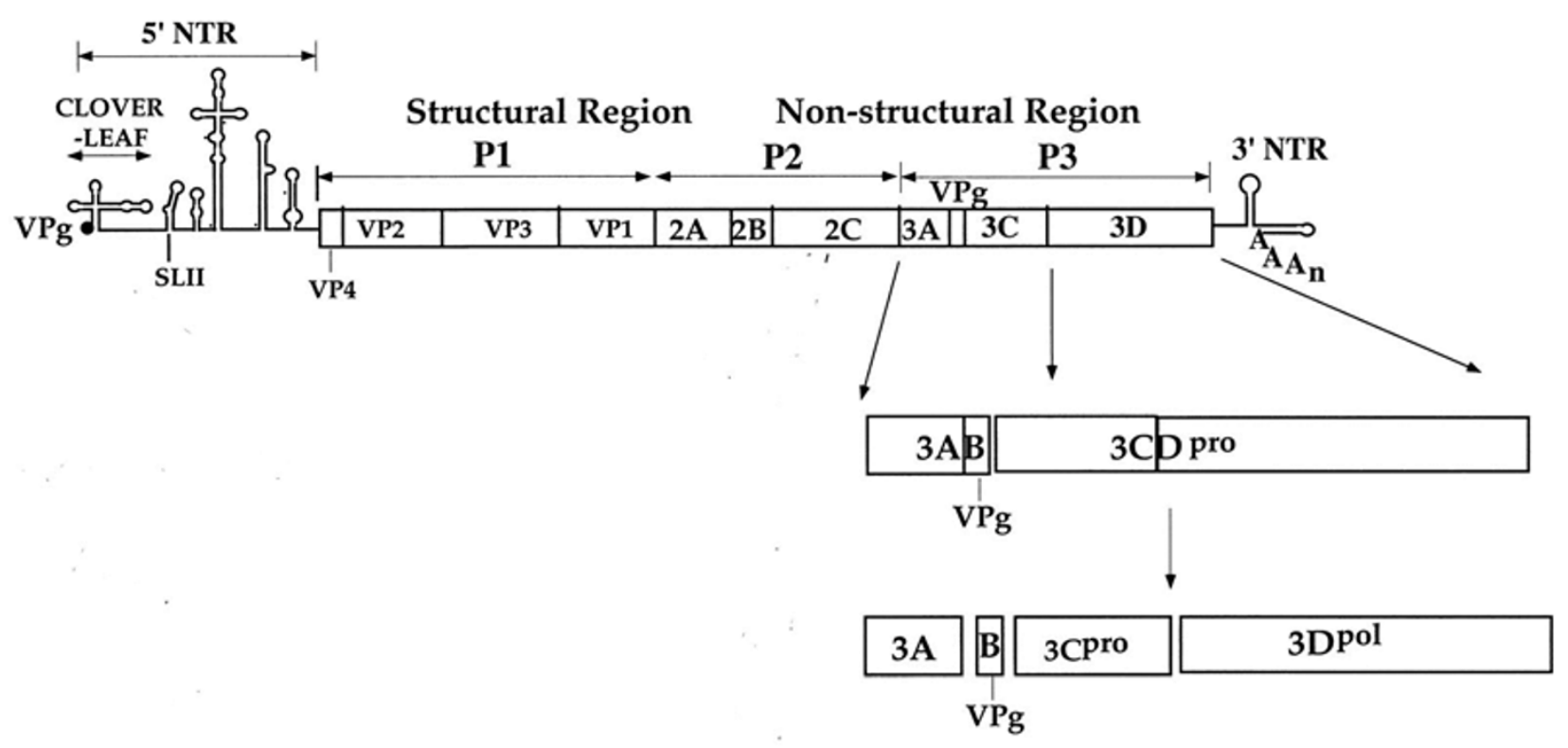

Figure I

Genomic structure of poliovirus and processing of the P3 domain of the polyprotein. The plus strand RNA genome of poliovirus is illustrated with the terminal protein VPg covalently linked to the $5^{\prime}$ end of the RNA. The $5^{\prime}$ nontranslated region (NTR) and 3' NTR are shown with single lines. The genome is terminated with a poly(A) tail. The polyprotein (open box) contains structural (PI) and nonstructural (P2 and P3 domains) that are processed into precursor and mature proteins. Processing of the $\mathrm{P} 3$ domain by $3 \mathrm{Cpro} / 3 \mathrm{CD}$ ro is shown enlarged. 
A.
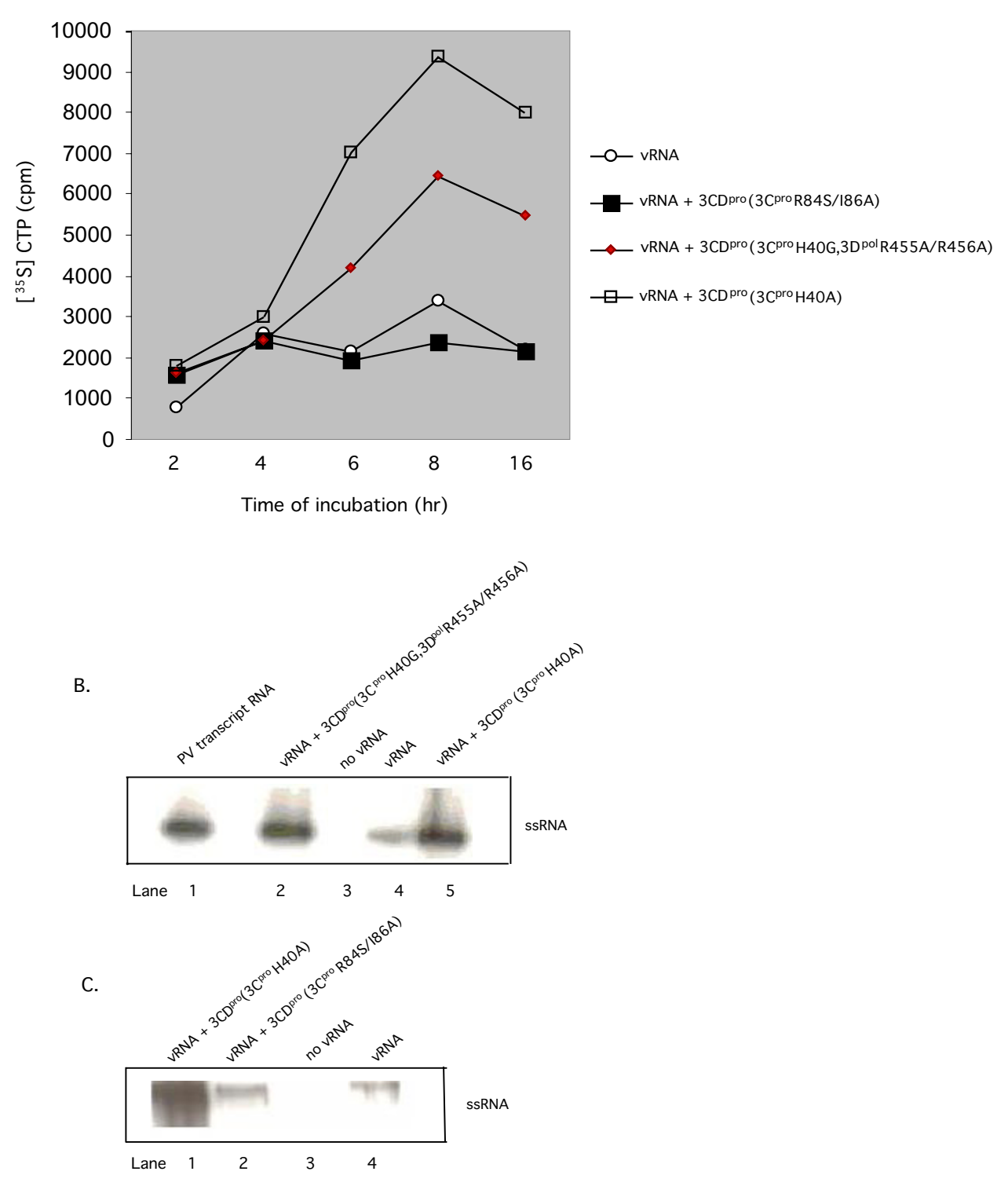

\section{Figure 2}

Effect of $3 \mathrm{CD}$ ro (3CproH40A) on viral RNA synthesis in the translation-RNA replication system. (A) Comparison of the stimulating activities of purified 3CDpro(3CproH40A) with mutant 3CDpro(3CproR84S//86A) or 3CDpro(3CproH40G; 3DpolR455A/ $\mathrm{R} 456 \mathrm{~A}$ ) on total viral RNA synthesis. Translation-RNA replication reactions were carried out in the presence of [ $\left.\alpha-{ }^{35} \mathrm{~S}\right] \mathrm{CTP}$. Where indicated purified 3CDpro proteins $(5.5 \mathrm{nM})$ or mRNA $(1.4 \mu \mathrm{g} / \mathrm{ml})$ was added at $\mathrm{t}=0 \mathrm{hr}$. Samples were taken at the indicated time points (Method I) and the total amount of label incorporated into polymer was determined with a filter-binding assay, as described in Materials and Methods. (B), (C) Comparison of the stimulating activities of purified 3CDpro(3CproH40A) with that of mutants 3CDPro(3CproH40G, 3DpolR455A/R456A) and 3CDpro(3CproR84S/I86A), respectively, on plus strand RNA synthesis. Translation-RNA replication reactions were carried out for $4 \mathrm{hr}$ and the replication complexes were isolated by centrifugation (Materials and Methods). The pellets were resuspended in translation reactions lacking viral RNA in the presence of $[\alpha-32 \mathrm{P}] \mathrm{CTP}$ and the samples were incubated for $\mathrm{I} \mathrm{hr}$ at $34^{\circ} \mathrm{C}$. Following extraction and purification the RNA products were applied to a nondenaturing agarose gel (Materials and Methods). A [ $\left.{ }^{32} \mathrm{P}\right] \mathrm{UMP}$-labeled PV transcript RNA was used as a size marker for full length PV RNA. 
tomer [11]. The protomers associate into pentamers and six pentamers form an icosahedral particle (empty capsid) enclosing the progeny plus strand RNA yielding provirions. It is unclear whether the progeny RNA is inserted into the empty capsid or whether the pentamers condense around the RNA $[12,13]$. Maturation is completed by the cleavage of VP0 into VP2 and VP4, possibly by a RNAdependent autocatalytic mechanism [11]. From the nonstructural viral proteins $2 C^{\text {ATPase }}[14]$ and VPg [15] have been proposed to have a role in encapsidation but their functions are not yet known.

The viral proteins most directly involved in RNA replication include protein $3 \mathrm{AB}$, the precursor of $3 \mathrm{~A}$, which is a small membrane binding and RNA binding protein, the terminal protein $\mathrm{VPg}$, RNA polymerase $3 \mathrm{Dpol}^{\mathrm{pol}}$ and proteinase $3 \mathrm{C}^{\mathrm{pro}} / 3 \mathrm{CD}^{\text {pro }}$. As a proteinase $3 \mathrm{CD}^{\text {pro }}$ is responsible for the processing of the capsid precursor [16] but it also has very important functions as an RNA binding protein [17-21]. It forms complexes with the 5 ' cloverleaf structure in PV RNA either in the presence of cellular protein PCBP2 $[18,22]$ or viral protein $3 \mathrm{AB}[19]$. The interaction between PCBP2, 3CDpro and the cloverleaf has been proposed to mediate the switch from translation to RNA replication [23] and the circularization of PV RNA through interaction with poly(A) binding protein bound to the poly(A) tail of the genome [24]. In addition, 3CDpro binds to the cre $(2 \mathrm{C})$ element $[20,21]$, and to the 3 'NTR in a complex with $3 A B$ [19]. Polypeptide $3 C D$ pro is also a precursor of proteinase $3 \mathrm{C}^{\text {pro }}$ and RNA polymerase $3 \mathrm{D}$ pol. The $3 \mathrm{Cpro}^{\mathrm{p}}$ domain of the polypetide contains both the proteinase active site and the primary RNA binding domain $[25,26]$. The function of the $3 \mathrm{D}^{\mathrm{pol}}$ domain appears to be to modulate these activities of the protein $[27,28]$ and it also contains RNA binding determinants [27]. By itself $3 \mathrm{D}^{\text {pol }}$ is the RNA dependent RNA polymerase, which possesses two distinct synthetic activities. It elongates oligonucleotide primers on a suitable template [29] and it links UMP to the hydroxyl group of a tyrosine in the terminal protein VPg [20]. The 3Dpol polypeptide possesses a structure similar to other nucleic acid polymerases of a right hand with palm, thumb and finger subdomains [30]. Interaction between polymerase molecules along interface I results in a head to tail oligomerization of the protein, which is important for its biological functions [31].

The aim of these studies was to determine how the addition of extra $3 C^{\text {pro }}$ protein to in vitro translation RNAreplication reactions, programmed with viral RNA, stimulates virus synthesis by 100 fold. In the presence of extra 3 CDpro we have observed a mild stimulation of both minus and plus strand RNA synthesis. The primary effect of $3 \mathrm{CD}^{\text {pro, }}$, however, is the enhancement of virus maturation resulting in a striking increase in the specific infectivity of the virus particles produced. Both of these processes are dependent on the RNA binding activity of the protein in the $3 \mathrm{Cpro}$ domain. Mutational analysis of 3CDpro suggests that the formation of $155 \mathrm{~S}$ mature virions also requires an intact interface $\mathrm{I}$ in the $3 \mathrm{D}^{\text {pol }}$ domain of the protein. Interestingly, plus strand RNA synthesis and virus production in translation RNA-replication reactions, programmed with PV transcript RNA, are not stimulated by 3CDpro

\section{Results \\ Effect of $3 C D$ pro $\left(3 C^{\text {pro }} 40 A\right.$ ) on viral RNA synthesis in in vitro translation-RNA replication reactions}

We have previously shown that translation of 3CDpro mRNA along with the viral RNA template in in vitro translation-RNA replication reactions, programmed with viral RNA, enhances total RNA synthesis about 3 fold [9]. The addition of 3CDpro, however, had no effect on the translation of the input viral RNA or processing of the polyprotein $[8,9]$. We have now extended these results by testing the effect of mutations in $3 \mathrm{CD}^{\text {pro }}$ on the ability of the protein to stimulate RNA synthesis. Translation-RNA replication reactions were incubated at $34^{\circ} \mathrm{C}$ either in the absence or presence of extra purified $3 \mathrm{CD}^{\text {pro }}\left(3 \mathrm{C}^{\text {pro }} \mathrm{H} 40 \mathrm{~A}\right)$. This protein, which contains a proteinase active site mutation, H40A, served as the positive control in all of our experiments. Samples were taken at 2-hour intervals and these were incubated with $[\alpha-35$ S]CTP for 1 hour. RNA synthesis was measured by the incorporation of label into polymer using a filter-binding assay. As shown in Fig. 2A, RNA synthesis is maximal 8 hrs after the start of translation and by $16 \mathrm{hr}$ the total amount of RNA present in the reaction decreases. At the peak of RNA synthesis there is a 3 -fold difference between reactions containing extra $3 \mathrm{CD}^{\text {pro }}\left(3 \mathrm{C}^{\mathrm{pro}} \mathrm{H} 40 \mathrm{~A}\right)$ and those to which no additional protein has been added.

Protein $3 C^{\text {pro }}$ is the precursor of both proteinase $3 \mathrm{C}^{\text {pro }}$ and polymerase $3 \mathrm{D}^{\mathrm{pol}}$. The $3 \mathrm{C}^{\text {pro }}$ domain contains both the proteinase and the RNA binding site $[25,26]$. While the primary RNA binding determinant of 3CDpro lies in $3 \mathrm{Cpro}$, lower affinity binding determinants are located in the $3 \mathrm{D}^{\mathrm{pol}}$ domain $[27,28]$. We have recently shown that a mutation (3Cpro $84 \mathrm{~A} / \mathrm{I} 86 \mathrm{~A}$ ) in the RNA binding domain of $3 \mathrm{CD}^{\text {pro }}$ abolishes that ability of the protein to stimulate virus production in the in vitro system [8]. To examine the effect of these mutations on RNA synthesis we have carried out translation-RNA replication reactions in the presence $3 C^{\text {pro }}$ (3CproR84S/I86A) mRNA. As shown in Fig. $2 \mathrm{~A}$, the mutation totally abolished the stimulatory activity of $3 \mathrm{CD}$ pro $(3 \mathrm{C}$ pro $\mathrm{H} 40 \mathrm{~A})$ in RNA synthesis suggesting that RNA binding is required for participation of the extra $3 \mathrm{CD}$ pro $\left(3 \mathrm{CProH}^{\mathrm{P}} \mathrm{AA}\right)$ in genome replication.

Our previous results indicated that the 3Dpol domain of $3 \mathrm{CD}$ pro is also required for the ability of $3 \mathrm{CD}$ pro to stimu- 
A.

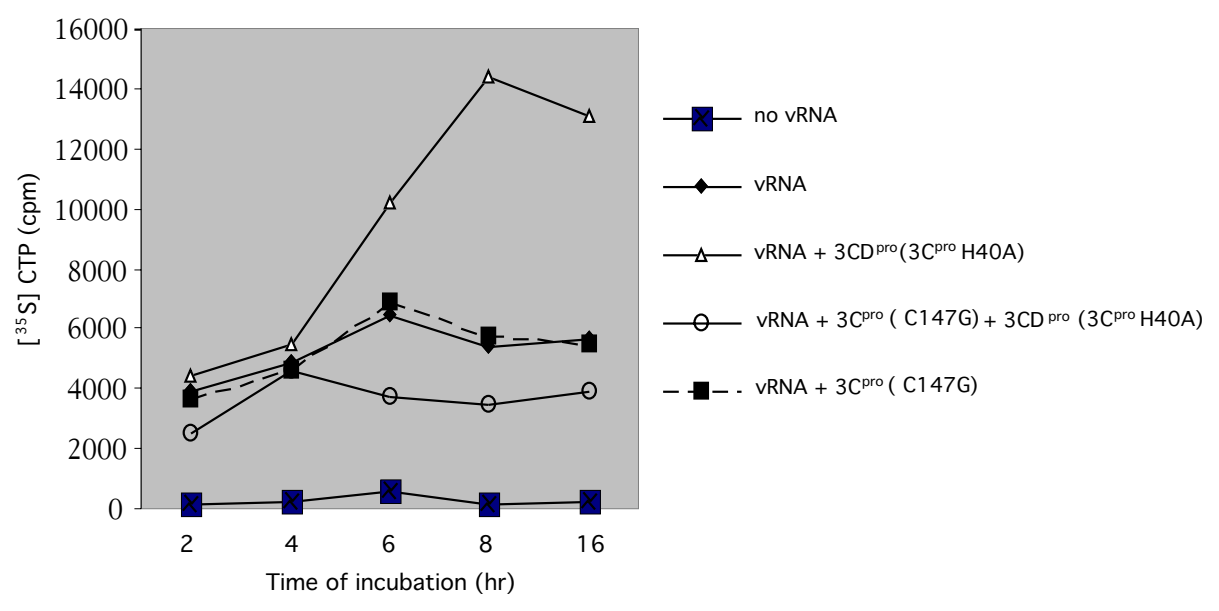

B.

c.
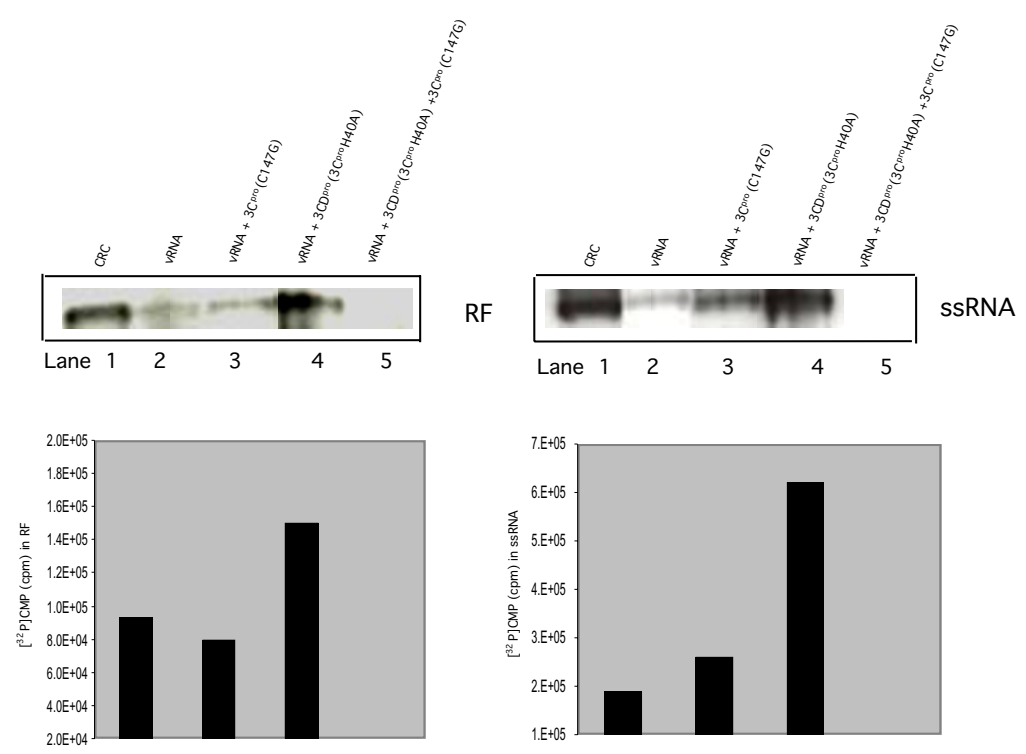

\section{Figure 3}

Inhibition of 3CDpro(3CproH40A)-stimulated RNA synthesis by $3 \mathrm{Cpro}(\mathrm{Cl}$ 47G) in vitro. (A) Inhibition of 3CDpro(3CproH40A)stimulated total viral RNA synthesis by $3 \mathrm{CPro}(\mathrm{CI} 47 \mathrm{G})$. Translation-RNA replication reactions were incubated for the indicated time periods in the presence of $\left[\alpha-{ }^{35}\right.$ S $]$ CTP (Method II) either in the absence or presence of 3 CDPro $(C p r o H 40 A)(5.5 \mathrm{nM})$. The total amount of label incorporated into polymer was determined with a filter-binding assay, as described in Materials and Methods. Where indicated $3 \mathrm{Cpro}(\mathrm{Cl} 47 \mathrm{G})$ was added to the reactions at $\mathrm{t}=0$ either alone or together with $3 \mathrm{CDpro}(3 \mathrm{CproH} 40 \mathrm{~A})$. (B), (C) Inhibition of 3CDPro(3CproH40A)-stimulated minus (B) and plus strand (C) RNA synthesis by 3Cpro(CI47G). Translation-RNA replication reactions were carried out in the presence of guanidine $\mathrm{HCl}$ for $4 \mathrm{hr}$ and the replication complexes were isolated by centrifugation (Materials and Methods). The pellets were resuspended in translation reactions lacking viral RNA in the presence of $[\alpha-32 \mathrm{P}] \mathrm{CTP}$ and the samples were incubated for I hr at $34^{\circ} \mathrm{C}$. Following extraction and purification of the RNAs the samples were analyzed on a nondenaturing agarose gel (Materials and Methods). RF: double stranded replicative form RNA; ssRNA: single stranded RNA; CRC: [32P]-labeled RNA products from crude replication complexes (Materials and Methods). 
late virus synthesis in the in vitro system [8]. This conclusion was based on the observation that two groups of mutations R455A/R456A [32] and D339A/S341A/D349A [33] in the $3 \mathrm{D}^{\mathrm{pol}}$ domain of the protein abolished the enhancement of virus yield in the in vitro system [8]. These complementary mutations in the thumb and palm subdomains of the protein, respectively, are located at interface I of the $3 \mathrm{D}^{\mathrm{pol}}$ protein structure and have been found to disrupt the oligomerization of the polypeptide $[32,33]$. Previous studies have indicated that oligomeric forms of the $3 \mathrm{Dpol}^{\mathrm{pol}}$ polypeptide are required for enzyme function [31]. To determine the effect of 3CD ${ }^{\text {pro }}$ (3C ${ }^{\text {Pro }}$ H40G, 3D ${ }^{\text {pol}}$ R455A/R456A) on RNA synthesis we added the purified mutant protein to translation RNA-replication reactions. This mutant protein exhibited a 2-fold stimulation in RNA synthesis, only slightly lower than what is obtained with $3 \mathrm{CD}^{\mathrm{pro}}\left(3 \mathrm{C}^{\text {pro }} \mathrm{H} 40 \mathrm{~A}\right)$ (Fig. 2A). This result indicates that 3Dpol residues R455 and R456 are not important for the stimulatory activity of 3CDpro in RNA synthesis. The effect of the other mutant $3 C^{\text {pro }}$ protein (3DpolD339A/S341A/D349A) on RNA synthesis was not analyzed.

\section{CDpro(3CproH40A) has a small stimulatory effect on both minus and plus strand RNA synthesis}

To examine the effect of 3 CDpro on plus strand RNA synthesis we translated the viral RNA for $4 \mathrm{hr}$ in the absence or presence of extra $3 \mathrm{CD}^{\text {pro }}\left(3 \mathrm{C}^{\text {pro }} \mathrm{H} 40 \mathrm{~A}\right)$. The initiation complexes [34] were isolated by centrifugation and resuspended in reaction mixtures lacking viral RNA but containing [ $\alpha-32$ P]CTP. After $1 \mathrm{hr}$ of incubation the RNA products were applied to a nondenaturing agarose gel together with a [ $\left.\alpha-{ }^{32} \mathrm{P}\right]$-labeled full-length poliovirus RNA transcript as a size marker (Fig. 2B, lane 1). The yield of plus strand RNA product obtained from these reactions was equally enhanced by the addition of extra $3 \mathrm{CD}^{\text {pro }}\left(3 \mathrm{C}^{\text {pro }} \mathrm{H} 40 \mathrm{~A}\right)$ or by mutant $3 \mathrm{CD}^{\mathrm{pro}}\left(3 \mathrm{C}^{\text {pro }} \mathrm{H} 40 \mathrm{G}\right.$, 3Dpol R455A/R456A) protein (Fig. 2B, compare lane 4 with lanes 2 and 5). No product was formed in the absence of a viral RNA template (Figs. 2B and 2C, lane 3). When 3CDpro mRNA, containing the R84S/I86A mutations in the RNA binding domain of $3 \mathrm{C}^{\text {pro, }}$, was cotranslated with the input viral RNA no stimulation of plus strand RNA synthesis was observed (Fig. 2C, compare lanes 2 and 4). These results indicate that RNA binding by the extra $3 \mathrm{CD}^{\text {pro }}\left(3 \mathrm{CPro}^{\mathrm{pro}} 4 \mathrm{OA}\right)$ is required for the stimulation of plus strand RNA synthesis but mutation R455A/ $\mathrm{R} 456 \mathrm{~A}$ in the $3 \mathrm{D}^{\mathrm{pol}}$ domain of the protein is not important for this process.

To compare the stimulatory effect of $3 \mathrm{CD}^{\text {pro }}$ (3Cpro $\left.\mathrm{H} 40 \mathrm{~A}\right)$ on both minus and plus strand RNA synthesis we used preinintiation replication complexes [2,34], which were collected after $4 \mathrm{hr}$ of incubation of the reactions in the presence of $2 \mathrm{mM}$ guanidine $\mathrm{HCl}$, a potent inhibitor of poliovirus RNA replication. The complexes were resuspended in reactions lacking viral RNA and guanidine and were incubated for an hour with $\left[\alpha-{ }^{32} \mathrm{P}\right] \mathrm{CTP}$. The RNA products were resolved on a nondenaturing agarose gel. Minus strand RNA synthesis was estimated from the amount of replicative form (RF), in which the minus strand is hybridized to the plus strand template RNA. As shown in Fig. 3B, minus and plus strand RNA synthesis are enhanced about 2-fold and 3-fold, respectively, when the reactions contain extra $3 \mathrm{CD}^{\mathrm{pro}}(3 \mathrm{C}$ proH40A). Poliovirus RF and ssRNA obtained from a reaction in which HeLa extracts were replaced by crude replication complexes (CRCs), isolated from PV-infected HeLa cells [35], were used as a size marker for the RF and the plus strand RNA (ssRNA) (Figs. 3B, and 3C, lane 1).

\section{The addition of $3 C^{\text {pro }}$ (3CproH40A) and $3 \mathrm{Cpro}$ (Cl47G) together totally blocks RNA synthesis in translation-RNA replication reactions}

We have recently shown that purified $3 \mathrm{C}^{\mathrm{pro}}(\mathrm{C} 147 \mathrm{G})$ protein, containing a proteinase active site mutation, when added alone to in vitro translation-RNA replication reactions, has no effect on virus yield. However, when included in reactions along with extra $3 \mathrm{CDpro}(3 \mathrm{C}$ proH40A) the production of virus is reduced about $1 \times 10^{4}$ fold [8]. To determine whether the inhibitory effect of $3 \mathrm{Cpro}^{\mathrm{P}}(\mathrm{C} 147 \mathrm{G})$ is at the level of RNA synthesis, we have examined the time course of RNA synthesis in the presence of both proteins by measuring the amount of $[\alpha-35$ S]UMP incorporated into polymer. As shown in Fig. $3 \mathrm{~A}$, the effect of these proteins on RNA synthesis fully parallels their effect on virus synthesis [8]. $3 \mathrm{CD}^{\text {pro }}\left(3 \mathrm{C}^{\text {pro }} \mathrm{H} 40 \mathrm{~A}\right)$ stimulates RNA synthesis up to 3fold while $3 \mathrm{C}^{\mathrm{pro}}(\mathrm{C} 147 \mathrm{G})$ alone exhibits no significant enhancement of the RNA yield. When the two proteins are added together there is essentially no increase in the total amount of RNA produced over a period of 16 hours. Control reactions, lacking a viral RNA template exhibited very little, if any, incorporation of label into a polymeric product (Fig. 3A). All other samples showed some incorporation of label into polymer, over what is measured in the absence of viral RNA (Fig. 3A). This is most likely a result of end labeling of the input viral RNA by newly translated $3 \mathrm{D}^{\mathrm{pol}}$ or priming by traces of degraded RNA.

To determine whether $3 \mathrm{C}^{\mathrm{pro}}(\mathrm{C} 147 \mathrm{G})$ inhibits plus or minus strand RNA synthesis we labeled with $[\alpha-32 \mathrm{P}] \mathrm{CMP}$ the RNA products formed in preinintiation replication complexes during a $1 \mathrm{hr}$ incubation period, as described above. The samples were analyzed on a nondenaturing agarose gel and as a size marker we used [ $\left.\alpha-{ }^{32} \mathrm{P}\right] \mathrm{CMP}-$ labeled RNA products made in CRCs (Figs. $3 \mathrm{~B}$ and 3C, lane 1). Two kinds of products were visible on the gel, the newly made single stranded RNA (ssRNA) and the double stranded replicative intermediate (RF). As shown on Fig. 

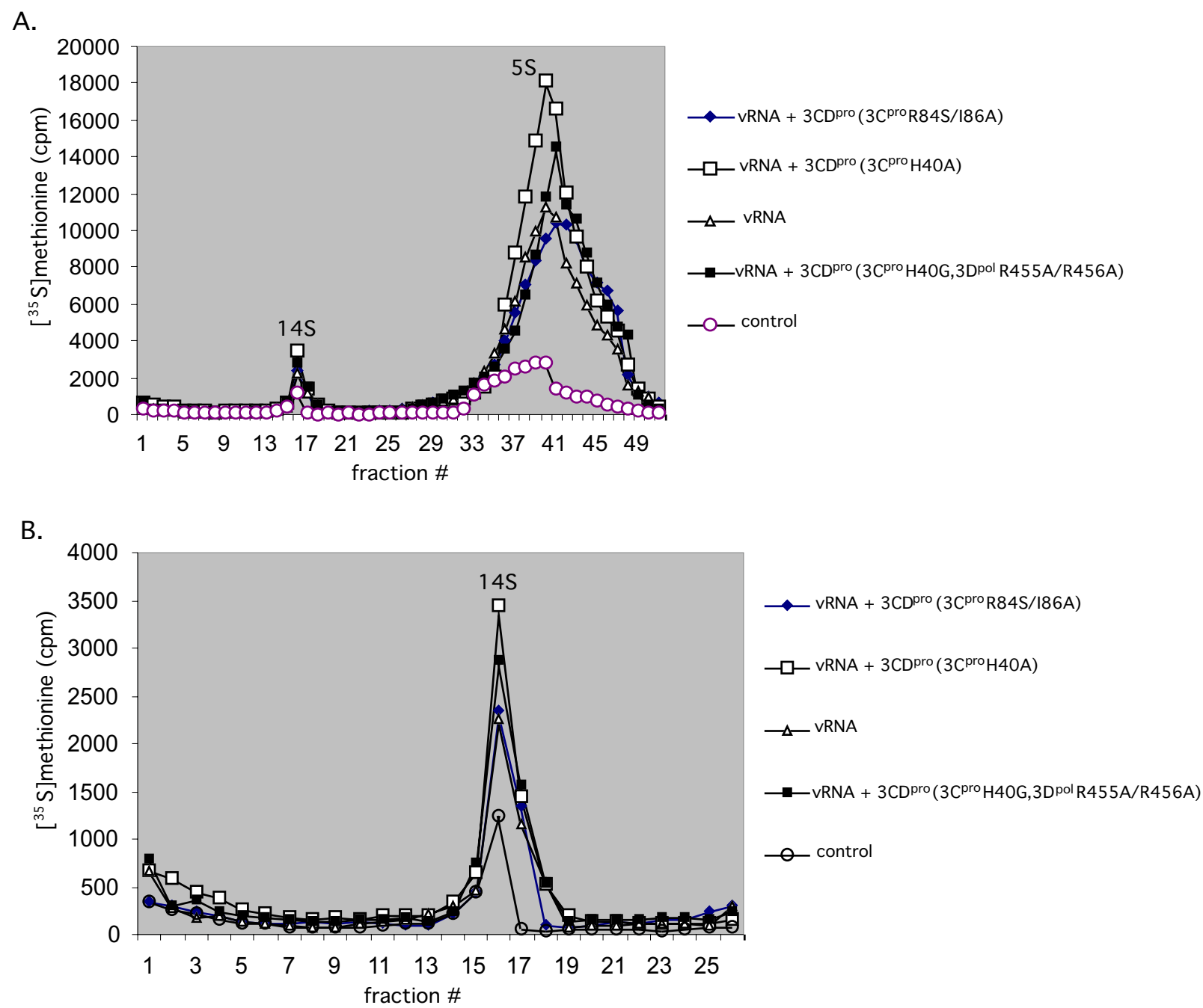

C.

\begin{tabular}{|c|c|c|c|}
\hline $125 S-155 S$ & $80 S$ & $14 S$ & $5 S$ \\
\hline$=$ & - & $-\cdots$ & +- \\
\hline
\end{tabular}

\section{Figure 4}

Effect of $3 \mathrm{CD}$ pro(3CproH40A) on the early stages of poliovirus assembly in vitro. Translation-RNA replication reactions were carried out in the presence of [ $\left.{ }^{35} \mathrm{~S}\right]$ TransLabel, as described in Materials and Methods. When indicated purified $3 \mathrm{CDpro}(3 \mathrm{CproH} 40 \mathrm{~A})$ protein $(5.5 \mathrm{nM})$ or $\mathrm{mRNA}(\mathrm{I} .4 \mu \mathrm{g} / \mathrm{ml})$ was added to the reactions at $\mathrm{t}=0 \mathrm{hr}$ and the samples were incubated for $16 \mathrm{hr}$ at $34^{\circ} \mathrm{C}$. Following RNase treatment and dialysis the samples were loaded on a 5-20\% sucrose gradient (Materials and Methods). The samples were centrifuged for $15 \mathrm{hr}$ at $40,000 \mathrm{RPM}$ in a SW4I rotor at $4^{\circ} \mathrm{C}$ for the separation of $5 \mathrm{~S}$ protomers and I4S pentamers. The amount of radioactivity at the bottom of the tubes of the gradients was not determined. (A) Comparison of samples obtained in the absence or presence of 3 CDpro $(3 \mathrm{CproH} 40 \mathrm{~A})$ and mutant 3 CDpro protein 3Dpol(H40G, R455A/R456A) or mRNA 3CPro(R84S/I86A). (B) The I4S peak from section (A) is shown enlarged; (C) Western blot analysis with anti VP2 antibodies of samples from the $5 \mathrm{~S}$ and $14 \mathrm{~S}$ peaks from the gradient shown on Fig. 4A. The same analysis of the $80 \mathrm{~S}$ and $155 \mathrm{~S}$ peaks from the gradient shown on Fig. 5. 
A.

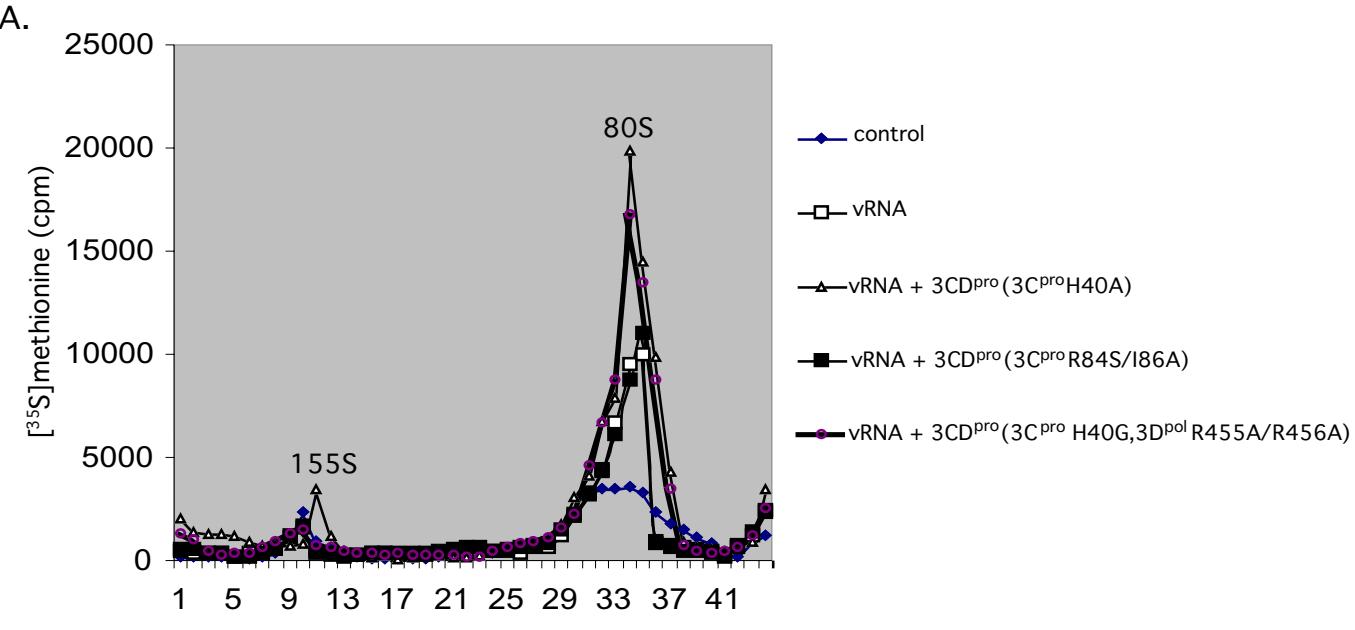

B.

fraction \#
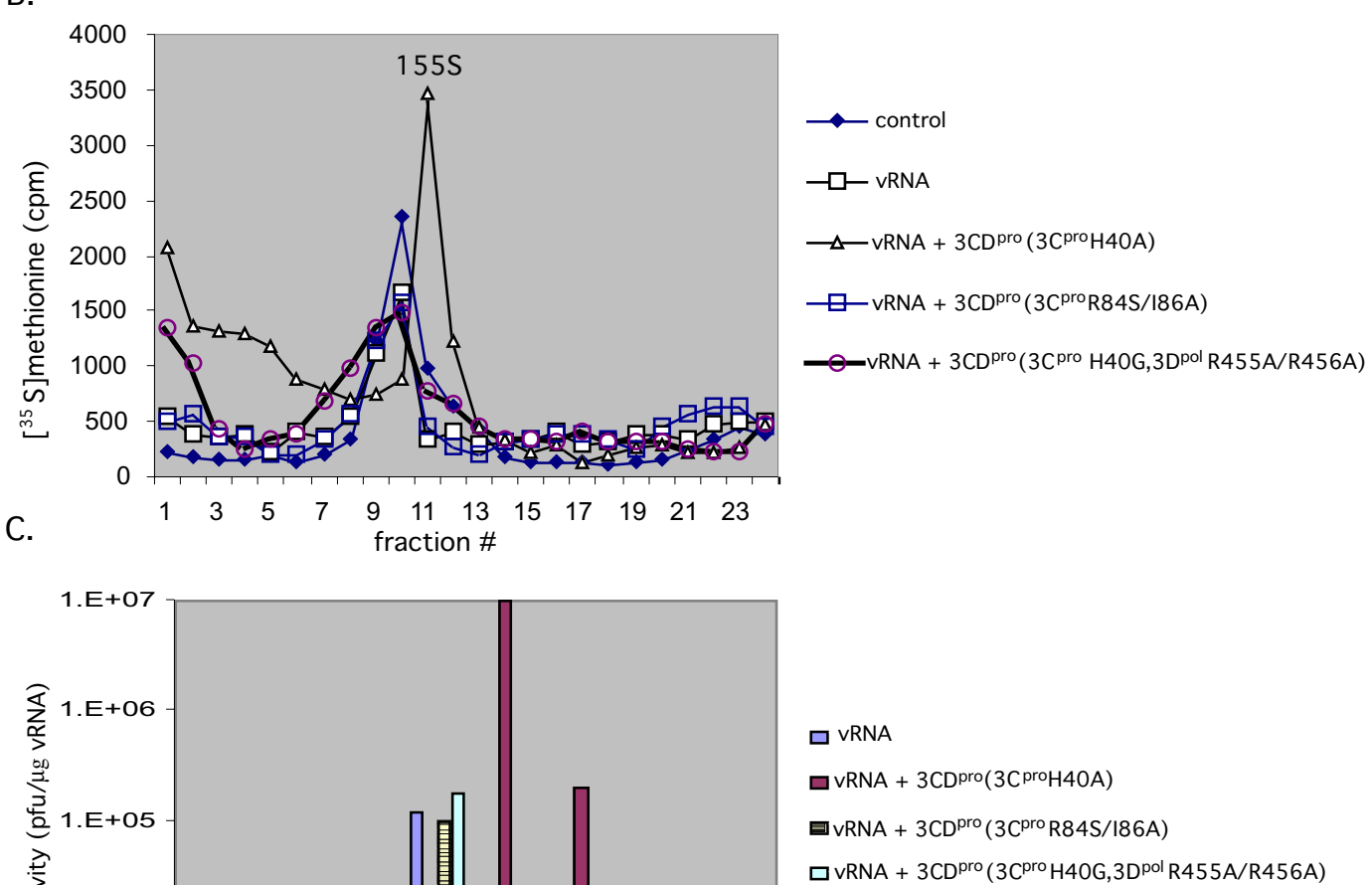

口VRNA + 3CD pro (3C pro H4OG,3D $^{\text {pol }}$ R455A/R456A)

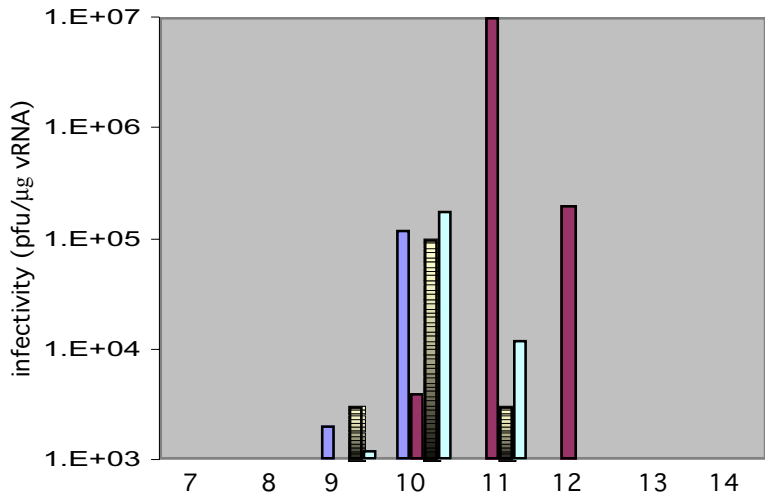

\section{Figure 5}

Effect of $3 \mathrm{CD}$ roo(3CproH40A) on the late stages of poliovirus assembly in vitro. Translation-RNA replication reactions were carried out in the presence of [ $\left.{ }^{35} \mathrm{~S}\right]$ TransLabel, as described in Materials and Methods. When indicated purified $3 \mathrm{CDPro}(3 \mathrm{CProH} 40 \mathrm{~A})$ protein $(5.5 \mathrm{nM})$ or $\mathrm{mRNA}(\mathrm{I} .4 \mu \mathrm{g} / \mathrm{ml})$ was added to the reactions at $\mathrm{t}=0 \mathrm{hr}$ and the samples were incubated for $16 \mathrm{hr}$ at $34^{\circ} \mathrm{C}$. As a control, poliovirus proteins labeled with [35S]TransLabel in vivo in HeLa cells, were used. Following RNase treatment and dialysis the samples were loaded on a 5-20\% sucrose gradient (Materials and Methods). The samples were centrifuged for $80 \mathrm{~min}$ at $40,000 \mathrm{RPM}$ in a SW4I rotor at $4^{\circ} \mathrm{C}$ for the separation of $80 \mathrm{~S}$ empty capsids and I55S virus particles (provirions and virions). (A) Comparison of samples obtained in the absence or presence of $3 \mathrm{CDPro}(3 \mathrm{CproH} 40 \mathrm{~A})$ and mutant 3CDpro protein 3Dpol(H40G, R455A/R456A) or mRNA 3Cpro(R84A/I86A). (B) The I55S peak from section (A) is shown enlarged. (C) Plaque assays of fractions 7-14 in the $155 \mathrm{~S}$ peak. 
A.

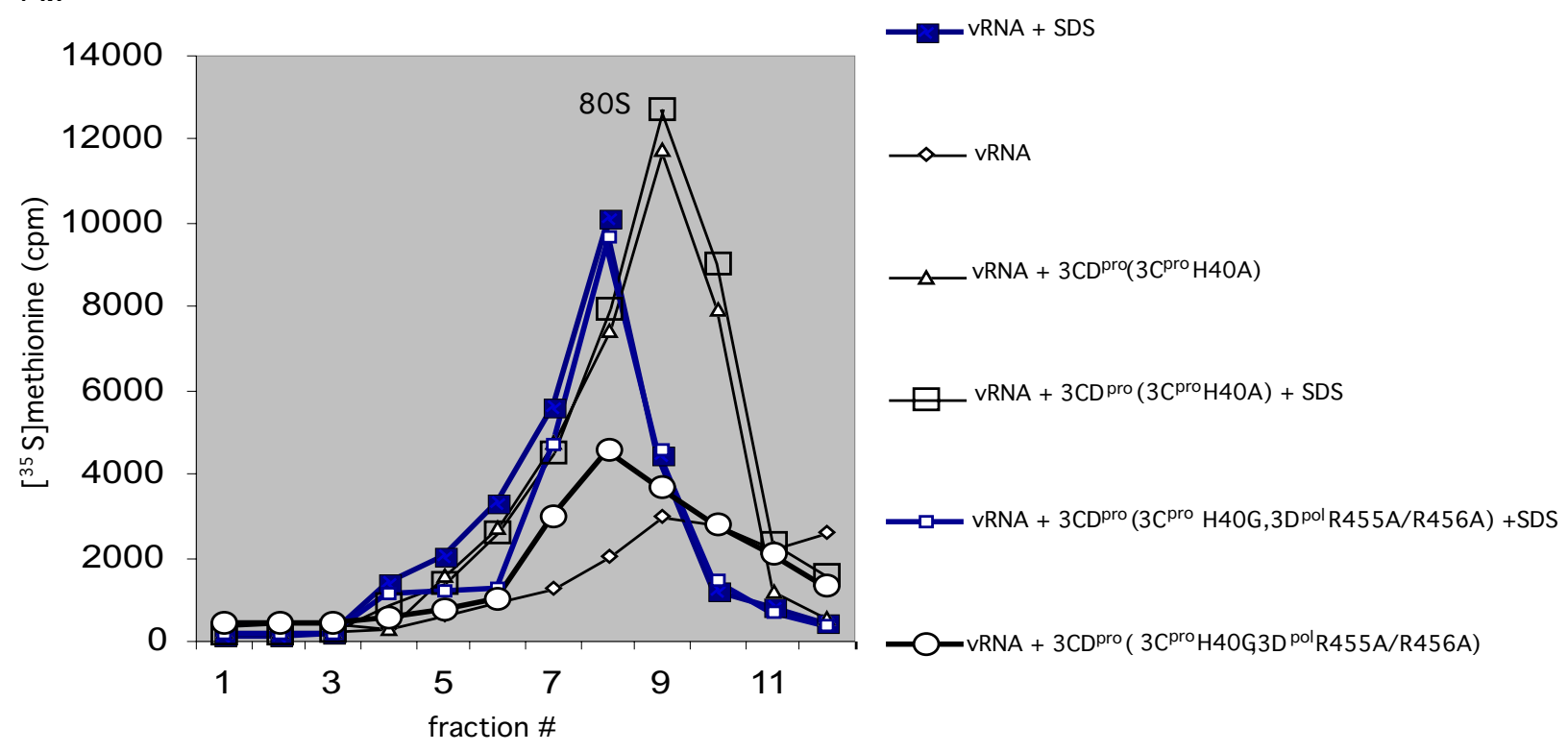

B.

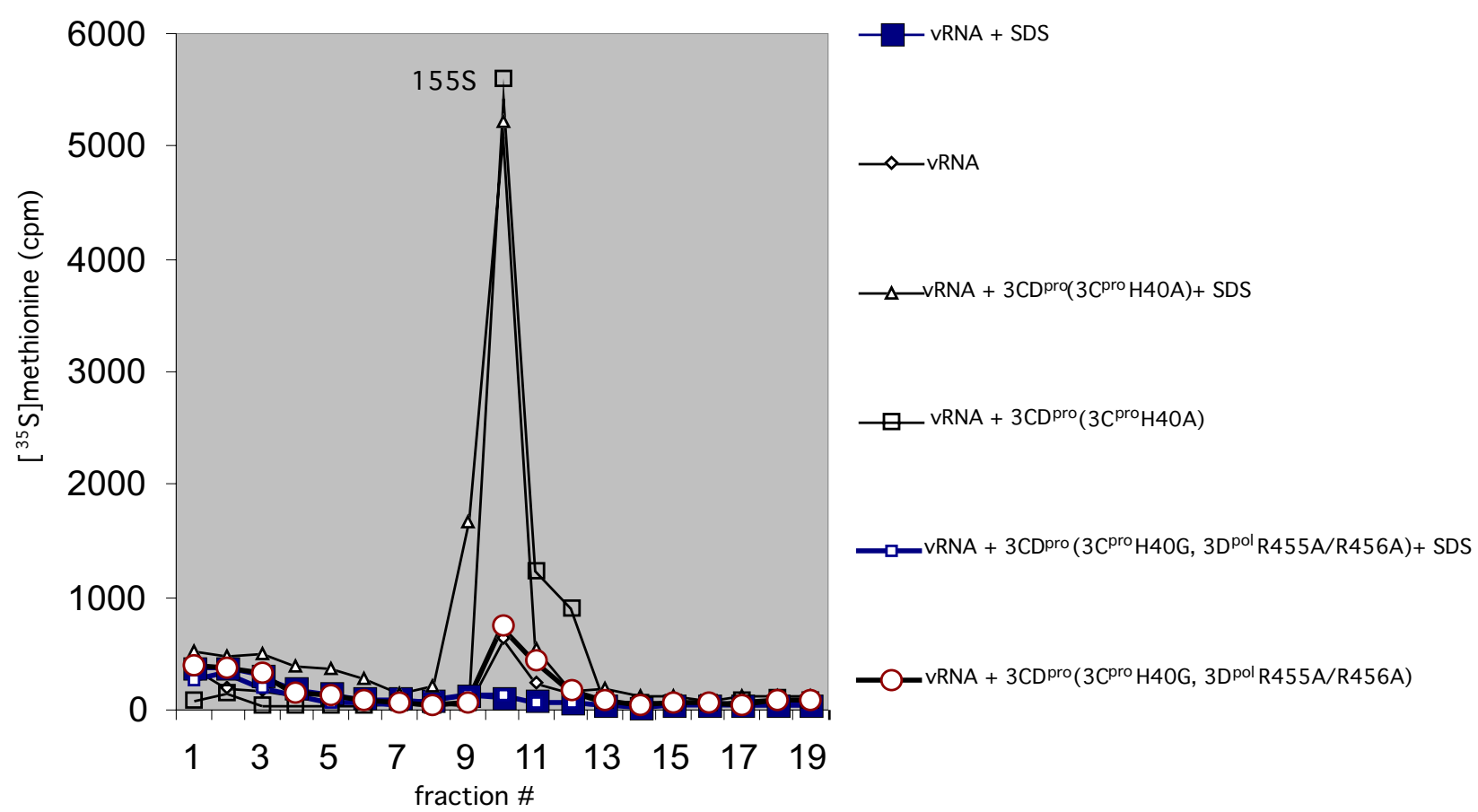

\section{Figure 6}

$3 \mathrm{CD}$ pro $(3 \mathrm{CproH} 40 \mathrm{~A})$ enhances the specific infectivity of virus particles produced in vitro. Translation-RNA replication reactions were carried out in the presence of [ $\left.{ }^{35} \mathrm{~S}\right]$ TransLabel, as described in Materials and Methods. Where indicated purified $3 \mathrm{CD}$ pro(3CproH40A) or 3CDPro (3CproH40G, 3DpolR455A/R456A) protein $(5.5 \mathrm{nM})$ was added to the reactions at $\mathrm{t}=0 \mathrm{hr}$ and the samples were incubated for $16 \mathrm{hr}$ at $34^{\circ} \mathrm{C}$. Following RNase treatment and dialysis, $0.1 \%$ of SDS was added to the samples, as indicated. They were loaded on a 5-20\% sucrose gradient (Materials and Methods) and centrifuged for 80 min at 40,000 RPM in a SW4I rotor at $4^{\circ} \mathrm{C}$. (A) the $80 \mathrm{~S}$ peak is shown; (B) the $155 \mathrm{~S}$ peak is shown. 
3B, 3Cpro(C147G) alone has very little, if any, effect on the yield of either of the 2 kinds of RNA products (Fig. 3B and $3 \mathrm{C}$, compare lanes 2 and 3 ). In the presence of both $3 \mathrm{C}^{\text {pro }}(\mathrm{C} 147 \mathrm{G})$ and $3 \mathrm{CD}^{\text {pro }}\left(3 \mathrm{C}^{\text {pro }} \mathrm{H} 40 \mathrm{~A}\right)$, however, the synthesis of both products is completely inhibited (Figs. 3B and 3C, compare lane 4 and lane 5).

\section{$3 C D^{\text {pro(}}$ (3CproH40A) has a small stimulating effect on the early steps of viral particle assembly}

The data shown before indicated a modest increase in viral RNA synthesis in the presence of extra $3 \mathrm{CD}^{\text {pro }}\left(3 \mathrm{C}^{\mathrm{pro}} \mathrm{H} 40 \mathrm{~A}\right)$ whereas the production of infectious virus was stimulated about 100 fold. The fact that there is such a large discrepancy between the extent of stimulation of RNA synthesis and virus production by $3 \mathrm{CDpro}(3 \mathrm{C}$ proH40A) suggested to us the possibility that this protein has an additional role at a subsequent step in the viral life cycle, the encapsidation of the progeny viral RNAs. To examine at which step of assembly this might occur, we labeled the viral proteins with [ $\left.{ }^{35} \mathrm{~S}\right]$-methionine in the in vitro reactions and analyzed the viral particles produced after $15 \mathrm{hr}$ incubation either in the absence or presence of $3 \mathrm{CD}^{\text {pro }}\left(3 \mathrm{C}^{\mathrm{pro}} \mathrm{H} 40 \mathrm{~A}\right)$. The samples were first loaded on a $5-20 \%$ sucrose gradient and sedimented for $15 \mathrm{hr}$, which resulted in the separation of the $5 \mathrm{~S}$ protomers and 14S pentamers from the large capsid precursors and mature virions [36]. As a size marker for these small capsid precursors, a parallel gradient was run, onto which a sample of [ ${ }^{35} \mathrm{~S}$ ]-labeled PV-infected HeLa cell lysate was applied (designated as control in Figs. 4 and 5). The amount of the $5 \mathrm{~S}$ and $14 \mathrm{~S}$ precursors is enhanced less than two fold by the presence of extra $3 \mathrm{CD}^{\text {pro }}\left(3 \mathrm{C}^{\mathrm{pro}} \mathrm{H} 40 \mathrm{~A}\right)$ in the reactions (Figs. $4 \mathrm{~A}$ and $4 \mathrm{~B}$ ). Similarly, reactions supplemented with mutant $3 \mathrm{CD}$ pro proteins, containing mutations either at the RNA binding

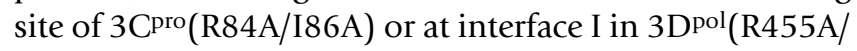
R456A), exhibited very little increase in the total amount of $5 \mathrm{~S}$ and $14 \mathrm{~S}$ particles, when compared to reactions lacking $3 \mathrm{CD}^{\text {pro }}\left(3 \mathrm{C}^{\text {pro }} \mathrm{H} 40 \mathrm{~A}\right)$ (Figs. $4 \mathrm{~A}$ and $\left.4 \mathrm{~B}\right)$.

To confirm the presence of uncleaved VP0 in the $5 \mathrm{~S}$ and $14 \mathrm{~S}$ peak fractions of the gradient derived from reactions supplemented with extra $3 \mathrm{CD}^{\text {pro }}\left(3 \mathrm{C}^{\text {pro }} \mathrm{H} 40 \mathrm{~A}\right)$, we used Western blot analyses with anti VP2 polyclonal antibody (Fig. 4C). As expected, only VP0 and no VP2 could be detected in the $5 \mathrm{~S}$ and $14 \mathrm{~S}$ peak fractions containing these small capsid precursors (Fig. 4C).

\section{CDpro(3CproH40A) has a small stimulatory effect on the late stages of particle assembly}

In the next set of experiments we examined the effect of $3 \mathrm{CD}^{\text {pro }}$ (3CproH40A) on the formation of $80 \mathrm{~S}$ (empty capsids) and $155 \mathrm{~S}$ particles (provirion and mature virus). As we discussed before, the role of the $80 \mathrm{~S}$ particle in viral assembly is unclear. The experimental evidence available at this time favors the hypothesis that empty capsids are dead-end products rather than true intermediates of particle assembly $[12,13]$. The particle thought to be the direct precursor of the mature virus is the provirion, a structure containing 60 copies of VP0, VP1 and VP3 and the viral RNA [37]. The difference between provirions and mature virus is that in the latter the particle is stabilized by the cleavage of VP0 to VP2 and VP4.

The $80 \mathrm{~S}$ and $155 \mathrm{~S}$ viral particles, labeled with [ ${ }^{35} \mathrm{~S}$ ]methionine in vitro, were separated by sedimentation in a $5-20 \%$ sucrose gradient for $80 \mathrm{~min}$. Under our experimental conditions the provirions (125S) and mature virus (155S) comigrate [36,37]. As shown in Fig. 5A the yield of $80 \mathrm{~S}$ particles is stimulated about 2 fold by $3 \mathrm{CDpro}(3 \mathrm{CproH} 40 \mathrm{~A})$ and by $3 \mathrm{CD}$ pro $(3 \mathrm{C}$ proH40G, 3DpolR455A/R456A) but not by 3CDpro (3Cpro R84S/ I86A). The formation of $155 \mathrm{~S}$ particles is enhanced about 3-7 fold by $3 \mathrm{CD}^{\text {pro }}\left(3 \mathrm{C}^{\text {pro }} \mathrm{H} 40 \mathrm{~A}\right)$ but not by the $3 \mathrm{CD}$ pro proteins that contain the $3 \mathrm{Dpol}^{\mathrm{R}} 455 \mathrm{~A} / \mathrm{R} 456 \mathrm{~A}$ or $3 \mathrm{C}$ pro R84S/I86A mutations (Figs 5A,5B, 6). To confirm the presence of mature virions in the $155 \mathrm{~S}$ peak fractions, derived from reactions supplemented with extra $3 \mathrm{CD}^{\text {pro }}$ (3C $\left.\mathrm{C}^{\text {pro }} \mathrm{H} 40 \mathrm{~A}\right)$, we used Western blot analysis with anti VP2 polyclonal antibody. As expected, both VP2 and VP0 were observed in the 155 S peak but only VP0 was present in the $80 \mathrm{~S}$ peak fractions of the gradient (Fig. 4C).

\section{CDpro(3CproH40A) strongly enhances the production of mature viral particles}

As we discussed above, the extra $3 \mathrm{CD}^{\mathrm{pro}}(3 \mathrm{C}$ proH40A) added to translation-RNA replication reactions has a relatively small stimulating effect both on RNA synthesis and on the incorporation of [ $\left.{ }^{35} \mathrm{~S}\right]$-methionine into capsid precursors, empty capsids or particles sedimenting at $155 \mathrm{~S}$. These results are difficult to reconcile with the 100-fold increase in infectious virus observed in translation RNAreplication reactions that are supplemented with extra $3 \mathrm{CD}^{\mathrm{pro}}\left(3 \mathrm{C}^{\mathrm{pro}} \mathrm{H} 40 \mathrm{~A}\right)[8,9]$. Taken together these findings suggested the possibility that the presence of extra $3 \mathrm{CD}$ pro(3CproH40A) enhances the specific infectivity of the virus particles produced, that is, it enhances the conversion of provirions to virions. To test this hypothesis we measured the yield of infectious virions in the peak fractions sedimenting at $155 \mathrm{~S}$ in sucrose gradients derived from in vitro reactions incubated with or without extra 3CDpro(3CproH40A). As shown on Fig. 5C, reactions to which extra $3 \mathrm{CD}^{\text {pro }}\left(3 \mathrm{C}^{\text {pro }} \mathrm{H} 40 \mathrm{~A}\right)$ protein was added yielded $155 \mathrm{~S}$ peaks containing 100 fold higher plaque forming units than reactions that were not supplemented with the protein. Interestingly, neither mutant 3CDpro proteins (3CproR84S/I86A or 3CproH40G, 3DpolR455A/ R456A) enhanced the virus yield in the 155S peak of the gradient (Fig. 5), an observation suggesting that both domains of the protein are required for this function. In a 
A.

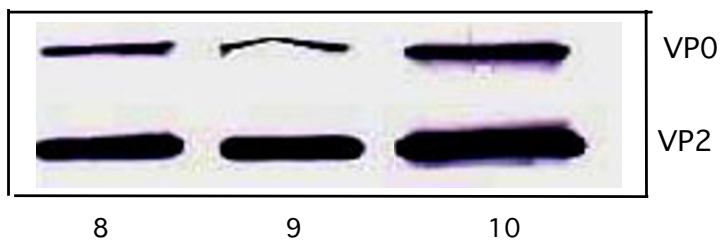

B.

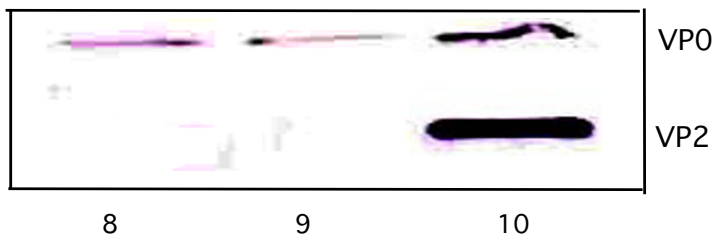

C.

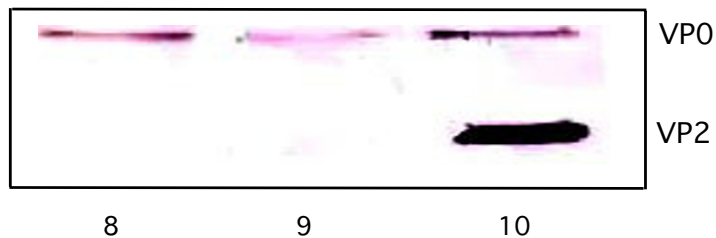

\section{Figure 7}

Comparison of the amount of VP0 and VP2 in I55S particles produced in reactions with and without extra

$3 \mathrm{CD}$ pro(3CproH40A). Translation RNA-replication reactions were carried out either in the absence or in the presence of extra 3CDpro(3CproH40A) or 3CDpro(3CproH40G,

3DpolR455A/R456A). The reaction products were separated on sucrose gradients, and the peak fractions were run on a SDS-polyacrylamide gel. Western blots were done with a polyclonal antibody to VP2 (Materials and Methods). The amount of VP0 and VP2 in fractions 8-10, in the I55S peak of the gradient shown on Fig. 6, was determined. (A) extra $3 \mathrm{CD}$ ro(3CproH40A) added; (B) no extra 3CDpro(3CproH40A) added; (C) 3CDpro(3CproH40G, 3DpolR455A/R456A) added. Lane I: fraction 8; lane 2, fraction 9; lane 3: fraction 10 of the 155S peak shown in Fig. 6.

parallel experiment we have estimated the total number of viral particles in the $155 \mathrm{~S}$ peak of the gradient by electron microscopy. We observed about 3 -fold increase in viral particles when $3 \mathrm{CD}^{\text {pro }}\left(3 \mathrm{C}^{\text {pro }} \mathrm{H} 40 \mathrm{~A}\right)$ was present in the translation-RNA replication reactions (data not shown).

To obtain further proof that the extra $3 \mathrm{CD}^{\text {pro }}\left(3 \mathrm{C}^{\text {pro }} \mathrm{H} 40 \mathrm{~A}\right)$ enhances the specific infectivity of the virus particles we used SDS treatment of the reaction products prior to sucrose gradient analysis. The incorporation of [35S]methionine into particles sedimenting at $80 \mathrm{~S}$ and $155 \mathrm{~S}$ was determined in reactions treated with SDS. It has been previously demonstrated that only mature virions but not provirions are stable in SDS [37]. As shown on Fig. 6A, there was no increase in $80 \mathrm{~S}$ particles in SDS-treated samples that contained extra $3 \mathrm{CD}^{\text {pro }}\left(3 \mathrm{C}^{\mathrm{pro}} \mathrm{H} 40 \mathrm{~A}\right)$ (Fig. 6A) suggesting that the sample did not contain significant amounts of provirions. On the other hand, the 80S empty capsid peak, obtained from reactions with no extra 3CDpro(3CproH40A) or with 3CDpro(3CproH40G, 3DpolR455A/R456A) mutant protein, increased by about 4 fold as a result of SDS treatment. Interestingly, most of the extra label that appear in this $80 \mathrm{~S}$ peak following SDS treatment is not derived from the $155 \mathrm{~S}$ peak, presumably by the dissociation of provirions into $80 \mathrm{~S}$ empty capsids and RNA (Fig. 6A). This suggested to us the possibility that in reactions lacking extra $3 \mathrm{CD}^{\text {pro }}\left(3 \mathrm{C}^{\mathrm{pro}} \mathrm{H} 4 \mathrm{OA}\right)$ some of the $80 \mathrm{~S}$ particles aggregated and pelleted in the gradient. To test this possibility we recovered and analyzed the pellets from the gradients. We observed that the amount of [ ${ }^{35} \mathrm{~S}$ ]-label in the pellet, derived from reactions with no extra 3CDpro, was 10 -fold higher than in pellets of reactions lacking the extra protein (data not shown). A Western blot analysis of the particles in the pellets indicated the presence of VP0 but no VP2 (data not shown).

As we discussed above, reactions containing extra $3 \mathrm{CD}^{\text {pro }}\left(3 \mathrm{C}^{\mathrm{pro}} \mathrm{H} 40 \mathrm{~A}\right)$ produced 3-7-fold higher amounts of $155 \mathrm{~S}$ particles than those that lacked the extra protein (Figs. 5A,5B, 6). These particles were stable to SDS treatment (Fig. 6B) suggesting that they are mature virions. In contrast, the small peak of $155 \mathrm{~S}$ particles obtained from reactions with no extra $3 \mathrm{CD}^{\text {pro }}\left(3 \mathrm{C}^{\mathrm{pro}} \mathrm{H} 40 \mathrm{~A}\right)$ or 3CDpro(3CproH40G，3DpolR455A/R456A) disappeared upon SDS treatment (Fig. 6B). These results suggest that under these conditions the 155 S peaks consists of large amount of provirions that are dissociated into $80 \mathrm{~S}$ particles and RNA by the SDS treatment. From the amount of [35S]-label resistant to SDS in the 155 S peaks (Fig. 6) it can be estimated that the presence of extra $3 \mathrm{CD}^{\text {pro }}\left(3 \mathrm{C}^{\text {pro }} \mathrm{H} 40 \mathrm{~A}\right)$ in translation-RNA replication reactions enhances the yield of mature virus about 40 -fold. Western blot analyses with anti VP2 antibodies of gradient samples 8-9 from the $155 \mathrm{~S}$ peak confirmed the presence of $\mathrm{VPO}$, indicating provirions in reactions lacking extra 3CDpro $\left.3 \mathrm{C}^{\mathrm{pro}} \mathrm{H} 40 \mathrm{~A}\right)$ (Fig. 7B) or containing

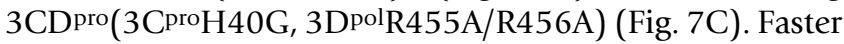
sedimenting particles in fraction 10 of this gradient contained some VP2 characteristic of mature virus. In contrast, reactions that contained extra $3 \mathrm{CD}$ pro $\left(3 \mathrm{CproH}^{\mathrm{N}} \mathrm{OA}\right)$ yielded a $155 \mathrm{~S}$ peak containing predominantly VP2, as judged by the Western analysis (Fig. 7A). Therefore, we conclude that the extra $3 \mathrm{CD}^{\mathrm{pro}}\left(3 \mathrm{C}^{\mathrm{pro}} \mathrm{H} 40 \mathrm{~A}\right)$ enhances the specific infectivity of the viral particles produced. 
A.
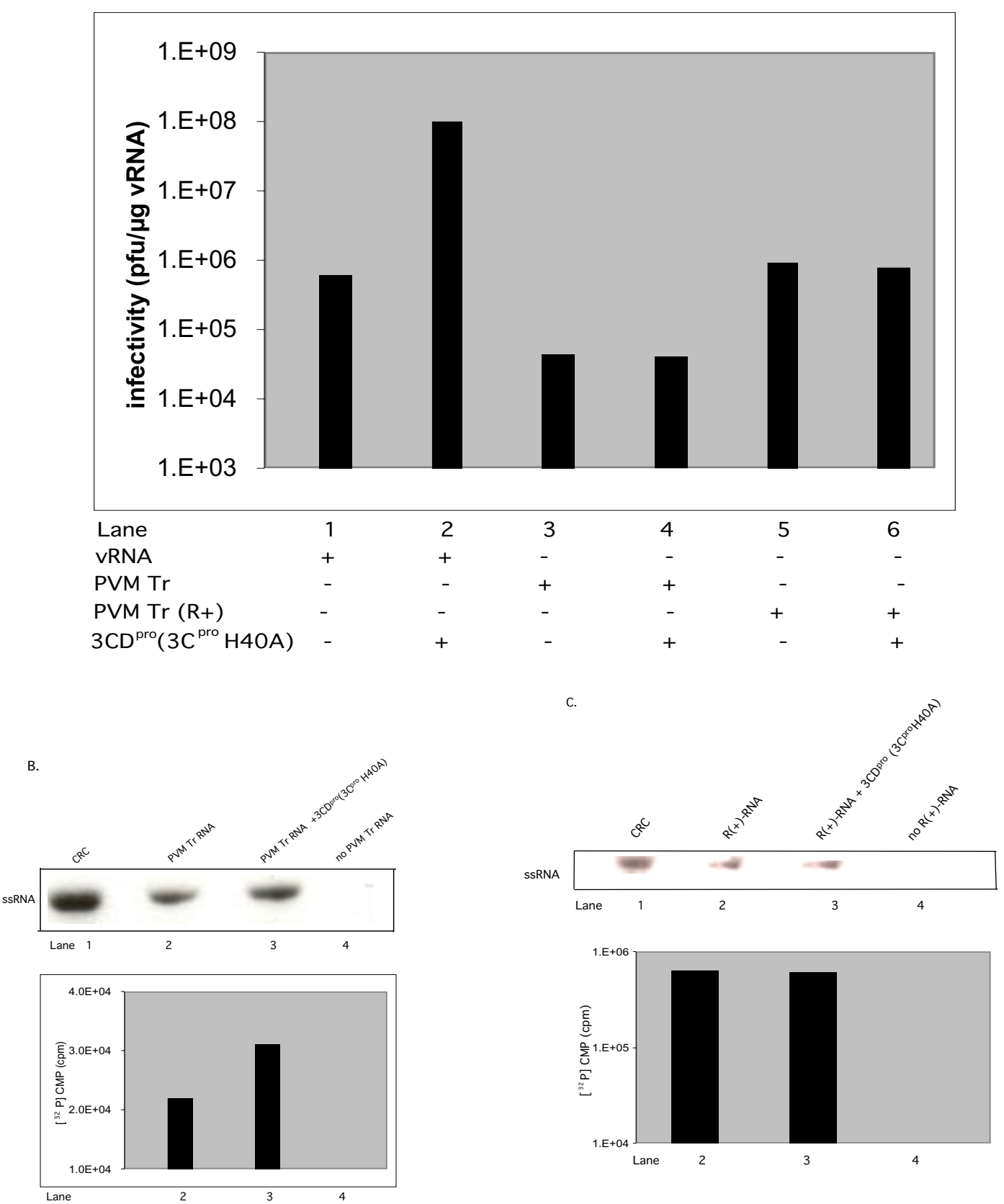

Figure 8

Extra $3 C D$ pro(3CproH40A) has no effect on virus production and RNA synthesis in reactions programmed with PV transcript RNA. Translation RNA-replication reactions were carried out, as described in Materials and Methods. The viral RNA template was replaced with a PV full-length transcript RNA made from a T7 promoter or with a ribozyme-treated transcript RNA. Where indicated $3 \mathrm{CD}$ pro $(3 \mathrm{CProH} 40 \mathrm{~A})(5.5 \mathrm{nM})$ was added at $t=0 \mathrm{hr}$. (A) Comparison of virus yields in reactions templated with viral RNA and transcript RNAs. (B) Plus strand RNA synthesis with initiation complexes isolated from reactions programmed with PV transcript RNA made from a T7 promoter (Materials and Methods). Lane I, CRC: [32P]-labeled RNA products obtained from crude replication complexes (Materials and Methods). (C) Plus strand RNA synthesis with initiation complexes isolated from reactions programmed with ribozyme-treated PV transcript RNA (R+ RNA). Lane I, CRC: [32P]labeled RNA products obtained from crude replication complexes (Materials and Methods). 
3CD pro(3CproH40A) does not stimulate RNA synthesis or virus production in translation RNA-replication reactions programmed with transcript RNA

Transfection of full-length transcript RNAs of poliovirus, made by T7 RNA polymerase, into HeLa cells initiate a complete replication cycle although the yield of virus is only $5 \%$ of that obtained in transfections with virion RNA [38]. In the in vitro translation-RNA replication system the yield of virus with transcript RNAs is also significantly reduced to about $1 \%$ of what is obtained when the reactions are supplemented with viral RNA $[39,40]$. This has been attributed to the presence of two extra GMPs at the 5 '-end of the transcript RNAs (pppGpGpUpU...), which are removed during replication to yield authentic viral RNA (VPg-pUpU...) [39]. Previous studies have demonstrated that the two GMPs at the 5' end of transcript RNAs do not interfere with minus strand RNA synthesis but greatly reduce the initiation of plus strand RNA synthesis in the in vitro system. Removal of the extra nucleotides with a cis-active hammerhead ribozyme resulted in templates that have regained most of their ability to support efficient plus strand RNA synthesis in the translation-RNA replication system [39].

To determine the effect of $3 \mathrm{CDpro}(3 \mathrm{Cpro} H 40 \mathrm{~A})$ on virus production, in reactions templated by transcript RNA, we have generated full-length PV transcript RNA from a T7 RNA polymerase promoter and used these to program in vitro translation-RNA replication reactions. In agreement with previous studies, we have observed that the virus yield is $50-100$ fold lower in reactions programmed with transcript RNA instead of viral RNA (Fig. 8A, compare lane 1 with lane 3 ). In contrast, the yield of virus from reactions templated by ribozyme-treated transcript RNAs was essentially the same as what was obtained from viral RNA (Fig. 8A, compare lane 1 with lane 5). Remarkably, the virus yield was not enhanced by $3 \mathrm{CD}^{\text {pro }}\left(3 \mathrm{C}^{\mathrm{pro}} \mathrm{H} 40 \mathrm{~A}\right)$ in either reactions using transcript RNAs with or without ribozyme-treatment (Fig. 8A, compare lanes 5 and 6 and also lanes 3 and 4, respectively).

Previous studies have demonstrated that in the in vitro translation-RNA replication system the amount of plus strand RNA product obtained from PV ribozyme-treated transcript RNA or viral RNA is about 100-fold higher than what is produced in reactions with ribozyme-deficient transcript RNAs [40]. To examine whether the lack of enhancement of virus production by $3 \mathrm{CD}^{\text {pro }}\left(3 \mathrm{C}^{\text {pro }} \mathrm{H} 40 \mathrm{~A}\right)$ in our reactions using a ribozyme-deficient transcript RNA is due to a defect in stimulating RNA synthesis we have measured the yield of plus strand RNA. Translation-RNA replication reactions were incubated for $4 \mathrm{hr}$ at $34^{\circ} \mathrm{C}$, the initiation complexes were collected by centrifugation and resuspended in reactions lacking transcript RNA. The RNA products were labeled with $[\alpha-32 \mathrm{P}] \mathrm{CTP}$ for $1 \mathrm{hr}$ and the products were applied to a nondenaturing gel. As shown in Fig. 8B, the presence of extra 3CDpro(3CproH40A) in such reactions has no stimulatory effect on plus strand RNA synthesis (compare lane 2 with lane 3 ). As a size marker for plus strand RNA we have included the $[\alpha-32 \mathrm{P}]-$ labeled full-length PV ssRNA product made in CRCs (Fig. $8 \mathrm{~B}$, lane 1$)$. The same results were obtained when RNA synthesis was measured with ribozyme-treated transcript RNA as template for translation-RNA replication (Fig. 8C, compare lane 2 with lane 3 ). It should be noted that the addition of extra 3CDpro(3CproH40A) to translation reactions of transcript PV RNA had no effect either on the efficiency of translation or the processing of the polyprotein (data not shown).

\section{The lethal R84S/l86A mutation in the 3Cpro domain of $3 C D$ pro cannot be complemented in vitro by wt $3 C D$ pro}

It has been previously demonstrated that in vivo complementation rarely occurs, and if it does, it is very inefficient $[7,41]$. However, this process is more efficient in the in vitro system because large amounts of complementing proteins are translated from the input RNAs and these are apparently accessible to the replication complex [6]. Our results described in this paper indicate that at least 2 functions of $3 \mathrm{CDpro}(3 \mathrm{C}$ ro $\mathrm{H} 40 \mathrm{~A})$ are complementable in the in vitro system and both of these functions depend on the RNA binding sequences of the protein. One of these is in RNA synthesis and the other one in virus maturation. To determine whether there are additional functions of 3Cpro/3CDpro that involve RNA binding we have attempted to complement the lethal R84S/I86A mutation in a full length PV transcript RNA either by cotranslation of wt 3CDpro mRNA or by the addition of purified $3 \mathrm{CD}^{\mathrm{pro}}\left(3 \mathrm{C}^{\mathrm{pro}} \mathrm{H} 40 \mathrm{~A}\right)$ to in vitro reactions. As shown in Table 1, the extra wt 3 CDpro does not restore the ability of the system to generate infectious virus. It should be noted that the 3CDpro translated both from the mutant PV RNA and the 3CDpro mRNA have full proteolytic activity (data not shown) and therefore these results are not due to a defect in protein processing. We have obtained the same negative results when we cotransfected the R84S/I86A mutant full length PV RNA with wt 3CDpro mRNA into HeLa cells (data not shown). These results can be interpreted to mean that: (1) 3CDpro has one or more additional RNA binding function(s), which is not complementable; (2) that an RNA binding function of 3 Cpro cannot be complemented by 3CDpro.

\section{Discussion}

We have previously shown that the level of active 3CDpro in in vitro translation-RNA replication reactions, programmed with viral RNA, is suboptimal for efficient virus synthesis and that the addition of extra 3CDpro compensates to some extent for this deficiency $[8,9]$ but the reason for this phenomenon remained unsolved. The results pre- 


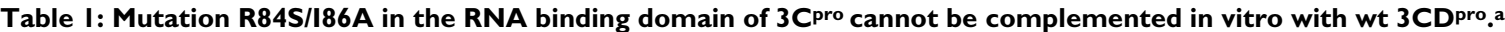

\begin{tabular}{|c|c|}
\hline Sample & 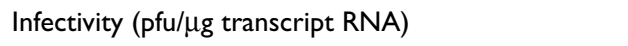 \\
\hline PVM(3CproR84S/186A) Tr RNA & 0 \\
\hline PVM(3CproR84S/186A) Tr RNA + I.4 $\mu \mathrm{g} / \mathrm{ml}$ 3CDpro mRNA & 0 \\
\hline PVM (3CproR84S/l86A) Tr RNA + 400 ng/ml 3CDpro protein & 0 \\
\hline
\end{tabular}

sented in this paper indicate that the stimulatory effect of 3 CDpro is both at the level of RNA synthesis and of virus maturation. Since translation, replication, and encapsidation are coupled processes during the growth of poliovirus $[13,42,43]$ one might conclude that the increase in the yield of mature virions simply reflects the stimulation of RNA synthesis. However, although this might be true to some extent, our results indicate that $3 \mathrm{CD}^{\mathrm{pro}}(3 \mathrm{C} \mathrm{Pro} \mathrm{H} 40 \mathrm{~A})$ exerts its enhancing activity at two distinct stages of the viral growth cycle. This conclusion is supported by three lines of evidence: (1) plus strand RNA synthesis is stimulated by $3 \mathrm{CD}^{\mathrm{pro}}$ (3C $\mathrm{C}^{\mathrm{r}} \mathrm{H} 40 \mathrm{~A}$ ) about 3 -fold but the yield of progeny virus increases 100 fold; (2) although 3CDpro(3CproH40G, 3DpolR455A/R456A), containing mutations at interface $\mathrm{I}$ in the $3 \mathrm{D}$ pol domain of the protein, enhance RNA synthesis nearly as efficiently as $3 \mathrm{CD}^{\text {pro }}\left(3 \mathrm{C}^{\text {pro }} \mathrm{H} 40 \mathrm{~A}\right)$ it does not stimulate the yield of mature virus; (3) only those reactions that contain extra $3 \mathrm{CD}^{\mathrm{pro}}(3 \mathrm{C}$ pro H40A) yield a $155 \mathrm{~S}$ peak in sucrose gradients with particles resistant to SDS treatment.

Our results with the in vitro translation-RNA replication system do not define the precise role of the extra 3CDpro in stimulating RNA synthesis. The evidence available thus far indicates that in the presence of extra

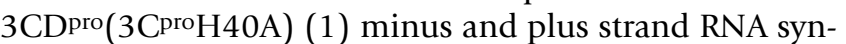
thesis are stimulated 2- and 3-fold, respectively; (2) the RNA binding sequences (R84/I86) in the 3Cpro domain of the polyprotein are required for the stimulation; (3) the integrity of interface I in the $3 \mathrm{D}^{\mathrm{pol}}$ domain of the polyprotein is not important. Whether plus strand RNA synthesis itself is stimulated by the presence of extra $3 \mathrm{CD}^{\text {pro }}$ or the amount of plus strands increases simply as a result of more minus strands remains to be determined. The fact that the RNA binding domain of the protein in 3Cpro is involved in stimulating RNA synthesis suggests that the extra 3CDpro forms a functional ribonucleoprotein complex (RNP) with an RNA sequence or structure in the viral genome. Poliovirus RNA contains at least 3 different cisacting elements that are involved in RNA replication. All of these bind $3 \mathrm{CD}^{\text {pro, }}$, the $5^{\prime}$ cloverleaf $[17,18,22]$, the cre $(2 \mathrm{C})$ element $[20,21]$ and the $3^{\prime} \mathrm{NTR}[19]$. From these 3 structures only the $5^{\prime}$ cloverleaf $[18,19,22,44]$ and the cre (2C) stem loop structure $[20,21,45]$ have been shown so far to form a biological relevant RNP complex with $3 \mathrm{CD}$ pro. The cloverleaf has been shown to be required for minus strand, and possibly also for plus strand RNA synthesis $[17,46]$. The RNP complexes of the cloverleaf with $3 C D$ pro, which also include either PCBP2 or $3 \mathrm{AB}$, are also required for both minus and plus strand RNA synthesis $[17,19,44,47]$.

The other important cis-replicating element involved in poliovirus RNA replication, which also binds $3 \mathrm{CD}^{\text {pro, }}$, is the $\operatorname{cre}(2 \mathrm{C})$ hairpin $[20,21,45]$. A conserved AAA sequence in this RNA element serves as template for the synthesis of VPgpU(pU), the primer for RNA synthesis $[20,45]$. The role of $3 C D$ pro in this reaction is believed to be to enhance the binding of the polymerase/VPg complex to the cre (2C) element [20,21,45]. The question whether the VPgpU(pU) made in this reaction is used exclusively for plus strand RNA synthesis [4] or also for minus strand synthesis remains controversial. The RNA binding sequences (R84/I86) of 3Cpro in 3CDpro but not amino acids R455/R456 at interface $I$ in the $3 \mathrm{D}^{\mathrm{pol}}$ domain are essential for the protein's stimulatory activity both in VPguridylylation in vitro $[20,33]$ and in the stimulation of RNA synthesis in the translation-RNA replication system. Taken together these results are consistent with a possible

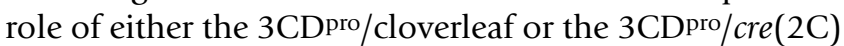
interactions in the stimulatory activity of the protein in RNA synthesis, which is dependent on the RNA binding activity of the $3 \mathrm{C}^{\text {pro }}$ domain.

We have previously reported the interesting observation that the addition of purified protein $3 \mathrm{C}^{\mathrm{pro}}(\mathrm{C} 147 \mathrm{G})$ along with $3 \mathrm{CD}$ pro(3CproH40A) to translation-RNA replication reactions reduces the virus yield about ten thousand fold [8]. In this paper we show that at least one of the reasons for the nearly total inhibition of virus production under these conditions is that there is a striking inhibition of both minus and plus strand RNA synthesis. One possible explanation of our in vitro results is that the two proteins form a complex, through intermolecular contacts in 3Cpro [48], which is inactive and either cannot bind to the RNA or the RNP complex is nonfunctional. Alternatively, the 
two proteins interact with the same RNA sequence or structure but only the 3CDpro/RNA complex is functional in RNA synthesis. Of the three cis-replicating elements contained within PV RNA both the cloverleaf and the cre(2C) element have been shown to form RNP complexes with either 3CDpro or 3Cpro $[17,21]$. In case of the cloverleaf only the $3 \mathrm{CD}$ pro/RNP complex is functional in replication but both protein-RNA complexes stimulate VPg-uridylylation on the $\operatorname{cre}$ (2C) RNA element [33]. These results suggest that the RNA sequence or structure involved in the stimulatory activity of 3CDpro in RNA synthesis in the in vitro system is the cloverleaf rather than the $\operatorname{cre}(2 \mathrm{C})$ element.

As we discussed above, the second step in the life cycle of PV where the extra 3CDpro(3CproH40A) appears to exert its stimulatory effect in vitro is during the late stages of particle assembly, and in particular during virus maturation. Although the addition of extra $3 \mathrm{CD}^{\mathrm{pro}}\left(3 \mathrm{C}^{\mathrm{pro}} \mathrm{H} 40 \mathrm{~A}\right)$ leads to a slight increase in the amount of small capsid precursors, the primary effect of the protein is at the step during which provirions are converted to mature viral particles. Although the mechanism of maturation cleavage is not fully understood it has been well established that the process is dependent on the presence of viral RNA [reviewed in [49]]. The exact function of $3 \mathrm{CDpro}$ (3CproH40A) in virus maturation is not yet known. Interestingly, both the RNA binding sequences in 3Cpro and the integrity of interface $\mathrm{I}$ in the 3Dpol domain of 3 CDpro are required for function but the proteolytic activity of the protein is dispensable. The fact that the RNA binding domain of $3 \mathrm{C}$ pro is essential for function indicates that $3 \mathrm{CD}^{\text {pro }}$ has to interact with a sequence or structure in the viral RNA. The observation that the integrity of interface I in the 3Dpol domain of the protein is also required for this process is more difficult to explain. Although the oligomerization of 3CDpro along interface I in 3Dpol has not yet been directly tested, recent structural studies of the RNA polymerase suggest that oligomerization of the protein along interface I is possible [30]. In addition, recent studies of genetically modified 3CDpro polypeptides in RNA replication strongly support a role of 3CDpro/3CDpro complexes, mediated by $3 \mathrm{D}^{\mathrm{pol}}$ domain contacts [50]. Whether the function of interface I in the 3Dpol domain of 3 CDpro in virus maturation is related to the RNA binding properties of the protein remains to be determined. Our recent in vitro studies indicate that mutation 3DpolR455A/ $\mathrm{R} 456 \mathrm{~A}$ in the context of 3CDpro alter the RNA binding properties of the protein such that twice as much of the mutant protein is required for optimal binding to a cre(2C) RNA probe than of the wt protein [Pathak and Cameron, unpublished results]. Oligomerization of 3CDpro might also be aided by intermolecular contacts between the $3 \mathrm{C}^{\text {pro }}$ domains of two molecules [48]. However, it should be noted that no interaction can be detected between 3Cpro molecules in chemical cross-linking experiments in vitro and only very poor, if any, complex formation can be observed between either 3Cpro/ $3 C^{\text {pro }}$ or $3 C^{\text {pro }} / 3 C^{\text {pro }}$ molecules in the yeast two hybrid system [51].

On the basis of these observations we propose 2 possible models for efficient virus maturation in the in vitro translation-RNA replication reactions supplemented with extra $3 \mathrm{CD}$ pro(3CproH40A). According to the first model $3 \mathrm{CD}$ ro(3CproH40A) interacts with the progeny plus strand RNA, possibly at the cloverleaf, and causes an important conformational change. This step requires the RNA binding activity of the $3 \mathrm{C}^{\text {pro }}$ domain of the protein but binding might also be enhanced by the oligomerization of the polypeptide along interface $\mathrm{I}$ in the 3Dpol domain. Subsequently the RNA interacts either with the pentamers or the empty capsid and it is encapsidated, yielding a provirion while $3 \mathrm{CD}^{\mathrm{pro}}\left(3 \mathrm{C}^{\mathrm{pro}} \mathrm{H} 40 \mathrm{~A}\right)$ leaves the complex. The correct conformation of the RNA inside the provirions affects the shape of the capsid such that now the cleavage of the VPOs is favored to complete maturation. The second model is similar to the first one except that now $3 \mathrm{CD}^{\text {pro }}\left(3 \mathrm{C}^{\text {pro }} \mathrm{H} 40 \mathrm{~A}\right)$ itself is encapsidated, bound to the progeny RNA. This keeps the RNA in the correct conformation inside the capsid so that the maturation cleavage of VP0 can occur. The second model is supported by previous studies by Newman and Brown who observed that $3 \mathrm{CD}^{\text {pro }}, 3 \mathrm{D}^{\mathrm{pol}}$ and $2 \mathrm{C}^{\text {ATPase }}$ proteins were contained within isolated poliovirus and foot-and-mouth disease virus particles [52]. In this context one should note that the scissile bond in VPO is located on the rim of a trefoilshaped depression on the capsid's inner surface, which has the potential of binding either RNA or other macromolecules [11]. However, we did not detect any 3CDpro in our $155 \mathrm{~S}$ peak derived from reactions with extra 3CDpro(3CproH40A) using Western blot analysis with either anti $3 \mathrm{C}^{\mathrm{pro}}$ or anti 3Dpol antibodies [data not shown]. In any case, the suboptimal concentration of functional 3CDpro in translation RNA-replication reactions might lead to progeny RNA molecules lacking the proper conformation for encapsidation and efficient virus maturation.

One of the factors that limits the use of the in vitro translation-RNA replication system in studies of RNA replication is the poor function of transcript RNAs as templates in the reaction, lowering the yield of progeny plus strand RNA and of virus to about $1 \%$ of what is obtained with virion RNA $[39,40]$. This has been attributed to the presence of two GMP molecules at the 5' end of RNAs transcribed from a T7 promoter [39]. We hoped that by supplying the inefficient in vitro reactions with an excess of $3 \mathrm{CD}^{\mathrm{pro}}\left(3 \mathrm{CPro}^{\mathrm{H}} \mathrm{H} 4 \mathrm{~A}\right)$ the synthesis of plus strands, and consequently the production of mature virus could be 
enhanced. To our surprise, this does not happen. The simplest explanation of these observations is that the level of endogenous $3 \mathrm{CD}$ pro is sufficient for the synthesis of the low level of plus strand RNA that is produced in the system. Therefore supplying the reactions with extra $3 \mathrm{CD}$ pro $(3 \mathrm{C}$ proH40A) would have no stimulatory effect. However, this explanation does not account for the fact that virus synthesis is not stimulated by $3 \mathrm{CD}^{\text {pro }}\left(3 \mathrm{C}^{\mathrm{pro}} \mathrm{H} 40 \mathrm{~A}\right)$ in reactions containing ribozymetreated transcript RNAs. The yield of virus in such reactions is 50-fold higher than in samples in which ribozyme-deficient transcripts were used as template for translation and RNA replication. The only known difference between viral RNA and ribozyme-treated transcript RNA is the lack of VPg in the latter structure. Therefore our results indicate that the presence of VPg at the 5 ' end of the input viral RNA $[53,54]$ is an important determinant of the ability of $3 \mathrm{CD}^{\text {pro }}\left(3 \mathrm{C}^{\mathrm{Pro}} \mathrm{H} 40 \mathrm{~A}\right)$ to stimulate RNA synthesis and production of viable virions. Interestingly, the addition of extra $3 \mathrm{CD}^{\text {pro }}$ (3CproH40A) at the beginning of incubation does not stimulate these processes once the newly made VPg-linked viral RNAs are used as templates for replication and packaging. This suggests that at least one of the stimulatory functions of $3 \mathrm{CD}^{\text {pro }}$ is required at the time RNA synthesis is initiated from the input VPglinked RNA template. Our results also suggest that either directly or indirectly the presence of VPg on the input RNA template is important for the stimulation by $3 \mathrm{CD}^{\text {pro }}\left(3 \mathrm{C}^{\mathrm{pro}} \mathrm{H} 40 \mathrm{~A}\right)$ of the encapsidation of the newly made viral RNAs. The involvement of VPg in encapsidation has been previously proposed by Reuer et al. [15] who observed that some lethal VPg mutations still permit near normal minus and plus strand RNA synthesis in vivo.

It has been known for some time that complementation between viral proteins is more efficient in the in vitro translation-RNA replication system than in vivo. This is most likely due to relatively large local concentrations of viral proteins that are translated from the input viral RNA template used in the in vitro reactions. The results described in this paper show that at least two functions of $3 \mathrm{CD}^{\text {pro }}$ are complementable in vitro. One is in RNA synthesis and the other in virus maturation and both of these processes require the RNA binding sequence of the $3 \mathrm{C}^{\text {pro }}$ domain. In an attempt to determine whether the RNA binding function of $3 \mathrm{CDpro}(3 \mathrm{C}$ proH40A) is required for additional processes in viral growth we tried to complement the lethal 3CproR84S/I86A mutation in the PV genome in vitro either by the addition of $3 \mathrm{CD}$ pro $\left.3 \mathrm{CproH}^{\mathrm{p}} \mathrm{OA}\right)$ protein or wt $3 \mathrm{CD}$ pro mRNA. We obtained no virus suggesting that one or more of the RNA binding functions of 3CDpro, distinct from the ones described by us, cannot be complemented in vitro. An alternate explanation of the observation is that $3 \mathrm{CD}^{\text {pro }}$ cannot substitute for $3 \mathrm{C}^{\mathrm{pro}}$ in one or more of its functions.
The results presented in this paper have yielded insights into the steps of the viral life cycle in which the extra $3 \mathrm{CD}^{\text {pro }}\left(3 \mathrm{C}^{\text {pro }} \mathrm{H} 40 \mathrm{~A}\right)$ exerts its stimulatory function in the translation-RNA replication system. Our results also suggest a new role for protein $3 \mathrm{CD}$ pro in the life cycle of poliovirus, in virus maturation, which is dependent on the integrity of interface I in the $3 \mathrm{D}^{\mathrm{pol}}$ domain of the protein. In addition, we have shown that a VPg-linked PV RNA linked template and the $3 \mathrm{C}$ pro domain of the $3 \mathrm{CD}^{\text {pro }}\left(3 \mathrm{C}^{\mathrm{pro}} \mathrm{H} 40 \mathrm{~A}\right)$ polypeptide are required both for the stimulation of RNA synthesis and for virus maturation. However, the exact mechanism of stimulation by $3 \mathrm{CD}$ pro both during RNA synthesis and particle assembly remains to be determined.

\section{Materials and methods Cells and viruses}

HeLa R19 cell monolayers and suspension cultures of HeLa S3 cells were maintained in DMEM supplemented with $5 \%$ fetal bovine calf serum. Poliovirus was amplified on HeLa R19 cells as described before. The infectivity of virus stocks was determined by plaque assays on HeLa R19 monolayers, as described before [55].

\section{Preparation of poliovirus RNA}

Virus stocks were grown and purified by $\mathrm{CsCl}$ gradient centrifugation [55]. Viral RNA was isolated from the purified virus stocks with a 1:1 mixture of phenol and chloroform. The purified RNA was precipitated by the addition of 2 volumes of ethanol.

\section{Preparation of HeLa cytoplamic extracts}

HeLa S10 extracts were prepared as previously described $[1,56]$ except for the following modifications: (1) packed cells from 2 liters of HeLa S10 were resuspended in 1.0 volumes (relative to packed cell volume) of hypotonic buffer; (2) the final extracts were not dialyzed.

\section{Translation-RNA replication reactions with HeLa cell-free extracts and plaque assays}

Viral RNA was translated at $34^{\circ} \mathrm{C}$ in the presence of unlabeled methionine, $200 \mu \mathrm{M}$ each CTP, GTP, UTP, and 1 $\mathrm{mM}$ ATP in a total volume of $25 \mu \mathrm{l}[1,5]$. After incubation for 12-15 hr the samples were diluted with phosphatebuffered saline and were added to HeLa cell monolayers. Virus titers were determined by plaque assay, as described previously $[1,55]$.

\section{Filter binding assays for measurement of total RNA synthesis}

Method I. Translation-RNA replication reactions (125 $\mu \mathrm{l})$ were incubated at $34^{\circ} \mathrm{C}$ in the presence of $62.5 \mu \mathrm{C}$ of $[\alpha-$ ${ }^{35}$ S]CTP (ICN, 600Ci/mmole) but lacking unlabeled CTP. At the indicated times samples were taken and the reactions were stopped by the addition of SDS to a final con- 
centration of $0.5 \%$. The samples were extracted with phenol-chloroform and the RNA was precipitated with ethanol. The pellets were resuspended in $10 \mathrm{mM}$ Tris $\mathrm{pH}$ 7.5, $1 \mathrm{mM}$ EDTA and were loaded on a DEAE-81 filter papers (Whatman). The filters were dried and subsequently washed three times with $5 \% \mathrm{Na}_{2} \mathrm{HPO}_{4}$, once with water and once with $70 \%$ ethanol, as described before [57]. Method II. Each translation-RNAreplication reaction was incubated separately at $34^{\circ} \mathrm{C}$. At the indicated times $(2,4,6,8$, and $16 \mathrm{hr}) 12.5 \mu \mathrm{C}$ of $[\alpha-35 \mathrm{~S}] \mathrm{CTP}$ was added and incubation was continued for $1 \mathrm{hr}$. The samples were treated and analyzed as described in Method I.

\section{Preinitiation RNA replication complexes}

Preinitiation RNA replication complexes were prepared as described previously [34] except for some minor modifications. Translation-RNA replication reactions, lacking initiation factors, were incubated for $4 \mathrm{hr}$ at $34^{\circ} \mathrm{C}$ either in the presence or absence of $2 \mathrm{mM}$ guanidine $\mathrm{HCl}$. The complexes were isolated by centrifugation, resuspended in $50 \mu \mathrm{l} \mathrm{HeLa} \mathrm{S10} \mathrm{translation/replication} \mathrm{reaction} \mathrm{mixture}$ without viral RNA, and incubated for $11 \mathrm{hr}$ at $34^{\circ} \mathrm{C}$.

\section{Plus and minus strand RNA synthesis}

Plus and minus strand RNA synthesis were determined as described previously [2]. Translation RNA replication reactions, programmed with viral RNA, were incubated for $4 \mathrm{hr}$ in the presence of $2 \mathrm{mM}$ guanidine $\mathrm{HCl}$. The preinitiation replication complexes were resuspended in translation-RNA replication reactions lacking viral RNA in the presence of $[\alpha-32 P] C T P$. The reactions were incubated at $34^{\circ} \mathrm{C}$ for $1 \mathrm{hr}$, the labeled RNAs were separated by native agarose gel electrophoresis, and the products were visualized by autoradiography. The reaction products were quantitated with a Phosphorimager (Molecular Dynamics Storm 800) by measuring the amount the amount of $\left[\alpha-{ }^{32} \mathrm{P}\right] \mathrm{CMP}$ incorporated into RNA.

Alternatively, plus strand RNA synthesis was measured in translation-RNA replication reactions that were incubated for $4 \mathrm{hr}$ at $34^{\circ} \mathrm{C}$, in the absence of guanidine $\mathrm{HCl}$, and the initiation complexes were isolated by centrifugation. They were resuspended in translation-RNA replication reactions lacking viral RNA but supplemented with [ $\alpha$ ${ }^{32} \mathrm{P}$ ]CTP. The samples were incubated for $1 \mathrm{hr}$ at $34^{\circ} \mathrm{C}$ and the RNA products were separated on a native agarose gel. The products were visualized by autoradiography.

\section{In vitro transcription and translation}

All plasmids were linearized with EcoRI prior to transcription by T7 RNA polymerase. The transcript RNAs were purified by phenol/chloroform extraction and ethanol precipitation. Translation reactions $(25 \mu \mathrm{l})$ containing 8.8 $\mu \mathrm{C}$ of Trans $\left[{ }^{35} \mathrm{~S}\right] \mathrm{Label}$ (ICN Biochemicals) were incubated for 4 hours at $34^{\circ} \mathrm{C}$ [5]. The samples were analyzed by electrophoresis on sodium deodecyl sulfate-12\% polyacrylamide gels, followed by autoradiography.

\section{RNA synthesis with crude replication complexes}

Crude replication complexes (CRCs) were prepared by a method similar to what has been described before [35]. HeLa cell monolayers $(15 \mathrm{~cm})$ were infected with PVM at a multiplicity of infection of 500. After $6 \mathrm{hr}$ incubation at $37^{\circ} \mathrm{C}$ the cells were resuspendend in hypotonic buffer [35] and were lysed with a Dounce homogenizer. Cell debris and nuclei were removed by centrifugation for 20 $\min$ at $33,000 \times \mathrm{g}$. The pellet was subsequently resuspended in $1 \mathrm{ml}$ of $10 \mathrm{mM}$ Tris- $\mathrm{HCl} \mathrm{pH} 8.0,10 \mathrm{mM} \mathrm{NaCl}$, and $15 \%$ glycerol. Aliquots were stored at $-80^{\circ} \mathrm{C}$.

RNA synthesis by CRCs was measured as described before [3]. In vitro translation-RNA replication reactions were assembled in which the HeLa extracts were replaced by CRCs (20\% by volume). The reaction contained $49 \%$ by volume of S10 buffer [2] and $25 \mu \mathrm{C}$ of [ $\alpha-32 \mathrm{P}] \mathrm{CTP}$.

\section{Sucrose gradient centrifugation of viral particles}

HeLa S10 translation-RNA replication reactions $(25 \mu \mathrm{l})$ were incubated in the presence of $8.8 \mu \mathrm{C}$ of [ $\left.{ }^{35} \mathrm{~S}\right]$ TransLabel (ICN Biochemicals) for $12 \mathrm{hr}$ at $34^{\circ} \mathrm{C}$. The excess unincorporated label was removed by dialysis. The samples were introduced into a Slide-a-lyzer (Pierce Endogen) dialysis cassette with a M.Wt cut-off of $10 \mathrm{kD}$ and were dialyzed several times against phosphate buffer at $4^{\circ} \mathrm{C}$ until essentially all the excess label was eliminated. After dialysis the samples were centrifuged at $14,000 \times \mathrm{g}$ to remove any precipitated material. The samples were diluted to $500 \mu \mathrm{l}$ and were centrifuged in a $5-20 \%$ sucrose density gradient in phosphate buffered saline containing $0.01 \%$ bovine serum albumin in a SW41 rotor at 40,000 $\mathrm{rpm}$ at $4^{\circ} \mathrm{C}$. To separate $80 \mathrm{~S}$ empty capsids and $155 \mathrm{~S}$ virus particles (provirions and virions) the gradients were cen-

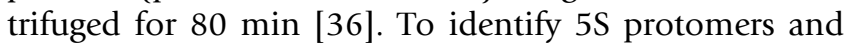
$14 \mathrm{~S}$ pentamers the gradients were centrifuged for $15 \mathrm{hr}$. Fractions $(0.5 \mathrm{ml})$ were collected from the bottom of the gradients and the radioactivity of each sample was determined by scintillation counting. In each sucrose gradient cetrifugation size markers were sedimented in parallel consisting of [ ${ }^{35}$ S]-labeled PV-infected HeLa cell extracts.

\section{Western blot analysis}

For the identification of the capsid proteins present in sucrose gradient fractions Western blot analysis was used [58]. Samples were loaded on a SDS-polyacrylamide gel (12.5\% acrylamide) and after separation the proteins were transferred to a nitrocellulose membrane (Protran; Schleicher\&Schuell). The membrane was probed with a rabbit polyclonal antibody to PV capsid protein VP2. 


\section{Electron microscopy}

Standard electron microscopy processing techniques were used for negative staining. Briefly, formvar coated, 200 mesh nickel grids were prepared. Grids, sample side down were floated on droplets of suspended poliovirus, followed by fixation in a solution of $1 \%$ glutaraldehyde in $0.1 \mathrm{M}$ phosphate buffered saline (PBS), pH 7.4. Samples were washed in PBS, then in water followed by phosphotungstic acid. The samples were viewed with a F. E. I. Tecnai 12 BioTwin electron microscope and digital images were captured with an ATM camera system. In each sample the viral particles were counted within a $20 \mathrm{~mm}^{2}$ area.

\section{Proteins}

The following PV proteins with a C-terminal his tag were expressed in E. coli and purified by nickel column chromatography (Qiagen): $3 \mathrm{CD}^{\text {pro }}\left(3 \mathrm{C}^{\text {pro }} \mathrm{H} 40 \mathrm{~A}\right)$, a proteinase active site mutant [20]; $3 \mathrm{C}^{\text {pro }}\left(3 \mathrm{C}^{\text {pro }} \mathrm{C} 147 \mathrm{G}\right)$, a proteinase active site mutant [33]. The purification of 3CDpro(3CproH40G, 3DpolR455A/R456A) was described previously [33]. This protein contains both a proteinase active site mutation (3CproH40G) and a mutation (3D ${ }^{\text {pol }}$ R455A/R456A) at interface I in the $3 \mathrm{D}^{\text {pol }}$ domain of the protein.

\section{Plasmids}

Poliovirus sequences were derived from plasmid pT7PVM, which contains the full-length (nt 1-7525) plus strand poliovirus CDNA sequence [38]. All constructs were sequenced to ensure their accuracy. The construction of plasmids pLOP315ser and pLOP315(3CproR84S/I86A) was described before $[8,9]$. Both plasmid DNAs were linearized with EcoRI prior to transcription with T7 RNA polymerase.

\section{Authors' contributions}

DF carried out all the experiments and made substantial contributions to the design of the experiments. HP contributed purified mutant enzymes for the study. CEC has contributed to the interpretation of the data and revised the manuscript critically. BR initiated the studies on this subject. EW contributed to the design of the experiments and revised the manuscript critically. AVP planned the experiments and wrote the manuscript. All authors read and approved the final manuscript.

\section{Acknowledgements}

We are grateful to D. W. Kim for his help in the preparation of HeLa cellfree extracts and for helpful discussions. We thank R. Andino for the plasmid containing PVI(M) CDNA preceded by a hammer-head ribozyme, prib(+)XPA and S. Van Horn for the electron microscopic analyses. This work was supported by two grants from the National Institute of Allergy and Infectious Diseases (E. Wimmer, R37 Al015122-30; and C. Cameron Al05353I).

\section{References}

I. Molla A, Paul AV, Wimmer E: Cell-free de novo synthesis of poliovirus. Science I99I, 254(5038): I647-I65I.

2. Barton DJ, Flanegan JB: Synchronous replication of poliovirus RNA: initiation of negative-strand RNA synthesis requires the guanidine-inhibited activity of protein 2C. J Virol 1997 , 7 I ( I I):8482-8489.

3. Fogg MH, Teterina NL, Ehrenfeld E: Membrane requirements for uridylylation of the poliovirus VPg protein and viral RNA synthesis in vitro. J Virol 2003, 77(2I): | |408-I|4|6.

4. Murray KE, Barton DJ: Poliovirus CRE-dependent VPg uridylylation is required for positive-strand RNA synthesis but not for negative-strand RNA synthesis. J Virol 2003, 77(8):4739-4750.

5. Molla A, Paul AV, Wimmer E: Effects of temperature and lipophilic agents on poliovirus formation and RNA synthesis in a cell-free system. J Virol 1993, 67( 10):5932-5938.

6. Towner JS, Mazanet MM, Semler BL: Rescue of defective poliovirus RNA replication by $3 \mathrm{AB}$-containing precursor polyproteins. J Virol 1998, 72(9):7191-7200.

7. Wimmer E, Hellen CUT, Cao X: Genetics of poliovirus. Annu Rev Genet 1993, 27:353-436.

8. Franco D, Pathak HB, Cameron CE, Rombaut B, Wimmer E, Paul AV: Stimulation of poliovirus synthesis in a HeLa cell-free in vitro translation-RNA replication system by viral protein 3CDpro. J Virol 2005, 79(I 0):6358-6367.

9. Verlinden $Y$, Cuconati A, Wimmer E, Rombaut B: The viral protein 3CD induces an equilibrium between the viral protein and RNA synthesis in a cell-free system for poliovirus replication. Arch Virol 2002, I47(4):731-744.

10. Paul AV: Possible unifying mechanism of picornavirus genome replication. In Molecular biology of picornaviruses Edited by: Semler BL, Wimmer E. ASM press:Washington, DC; 2002:227-246.

II. Rossman MG: Picornavirus structure overview. In Molecular biology of picornaviruses Edited by: Semler BL, Wimmer E. ASM press:Washington, DC; 2002.

12. Verlinden Y, Cuconati A, Wimmer E, Rombaut B: Cell-free synthesis of poliovirus: I4S subunits are the key intermediates in the encapsidation of poliovirus RNA. J Gen Virol 2000, 8 I ( I I):275 I-2754.

13. Nugent $\mathrm{Cl}$, Kirkegaard K: RNA binding properties of poliovirus subviral particles. J Virol 1995, 69(I): I 3-22.

14. Vance LM, Moscufo N, Chow M, Heinz BA: Poliovirus 2C region functions during encapsidation of viral RNA. J Virol 1997, 7 I ( I I):8759-8765.

15. Reuer Q, Kuhn RJ, Wimmer E: Characterization of poliovirus clones containing lethal and nonlethal mutations in the genome-linked protein VPg. J Virol 1990, 64(6):2967-2975.

16. Ypma-Wong MF, Dewalt PG, Johnson VH, Lamb JG, Semler BL: Protein $3 C D$ is the major poliovirus proteinase responsible for cleavage of the PI capsid precursor. Virology 1988, I 66(I):265-270.

17. Andino R, Rieckhof E, Achacoso PL, Baltimore D: Poliovirus RNA synthesis utilizes an RNP complex formed around the 5 '-end of viral RNA. EMBO J 1993, I 2(9):3587-3598.

18. Gamarnik AV, Andino R: Interactions of viral protein 3CD and poly $(r C)$ binding protein with the 5 ' nontranslated region of the poliovirus genome. J Virol 2000, 74(5):2219-2226.

19. Harris K, Xiang W, Alexander L, Lane WS, Paul AV, Wimmer E: Interaction of the poliovirus polypeptide 3 CDpro with the $5^{\prime}$ and 3 ' termini of the poliovirus genome: identification of viral and cellular factors cofactors needed for binding. J Biol Chem 1994, 269(43):27004-27014

20. Paul AV, Rieder E, Kim DW, van Boom JH, Wimmer E: Identification of an RNA hairpin in poliovirus RNA that serves as the primary template for the uridylylation of VPg in vitro. J Virol 2000, 74(22): 10359-10370.

21. Yin J, Paul AV, Wimmer E, Rieder E: Functional dissection of a poliovirus cis-acting replication element [PV-cre(2C)]: analysis of single- and dual-cre viral genomes and proteins that bind specifically to PV-cre RNA. J Virol 2003, 77(9):5I52-5 I 66.

22. Parsley TB, Towner JS, Blyn LB, Ehrenfeld E, Semler BL: Poly(rC)binding protein 2 forms a ternary complex with the 5 -terminal sequences of poliovirus RNA and the viral 3CD proteinase. RNA I997, 3(10): I I 24- I I34. 
23. Gamarnik AV, Andino R: Switch from translation to RNA replication in a positive strand RNA virus. Genes Dev 1998 , I 2( I 5):2293-2304.

24. Herold J, Andino R: Poliovirus RNA replication requires genome circularization through a protein bridge. Mol Cell 200I, 7(3):58I-59I.

25. Blair WS, Parsley TB, Bogerd HP, Towner JS, Semler BL, Cullen BR: Utilization of a mammalian cell-based RNA binding assay to characterize the RNA binding properties of picornavirus $3 \mathrm{C}$ proteinases. RNA 1998, 4(2):215-225.

26. Hammerle T, Molla A, Wimmer E: Mutational analysis of the proposed FG loop of poliovirus proteinase $3 \mathrm{C}$ identifies amino acids that are necessary for $3 C D$ cleavage and might be determinants of a function distinct from proteolytic activity. J Virol 1992, 66( I 0):6028-6034.

27. Cornell CT, Semler BL: Subdomain specific functions of the RNA polymerase region of poliovirus 3CD polypeptide. Virology 2002, 298(2):200-2।3.

28. Parsley TB, Cornell CT, Semler BL: Modulation of the RNA binding and protein processing activities of poliovirus polypeptide 3CD by the viral RNA polymerase domain. J Biol Chem 1999, 274( I 8): | 2867-I2876.

29. Flanegan JB, Baltimore D: Poliovirus-specific primer-dependent RNA polymerase able to copy poly(A). Proc Natl Acad Sci USA 1977, 74(9):3677-3680

30. Thompson AA, Peersen OB: Structural basis for proteolysisdependent activation of the poliovirus RNA-dependent RNA polymerase. EMBO J 2004, 23(I 7):3462-347I.

31. Pata JD, Schultz SC, Kirkegaard K: Functional oligomerization of poliovirus RNA dependent RNA polymerase. RNA 1995 I(5):466-477.

32. Diamond SE, Kirkegaard K: Clustered charged-to-alanine mutagenesis of poliovirus RNA-dependent RNA polymerase yields multiple temperature sensitive mutants defective in RNA synthesis. J Virol 1994, 68(2):863-876.

33. Pathak HB, Ghosh SKB, Roberts AW, Sharma SD, Yoder JD, Arnold J), Gohara DW, Barton DJ, Paul AV, Cameron CE: Structure-function relationships of the RNA-dependent RNA polymerase from poliovirus (3Dpol). A surface of the primary oligomerization domain functions in capsid precursor processing and VPg uridylylation. J Biol Chem 2002, 277(35):3 I 55I-3I 562.

34. Barton DJ, Black EP, Flanegan JB: Complete replication of poliovirus in vitro: preinitiation RNA replication complexes require soluble cellular factors for the synthesis of VPglinked RNA. J Virol 1995, 69(9):5516-5527.

35. Takeda N, Kuhn RJ, Yang CF, Takegami T, Wimmer E: Initiation of poliovirus plus-strand RNA synthesis in a membrane complex of infected HeLa cells. J Virol 1986, 60(I):43-53.

36. Lee MW, Wang W: Human rhinovirus type I6: Mutant VI 2 I OA requires capsid-binding drug for assembly of pentamers to form virions during morphogenesis. I Virol 2003, 77( I I ):6235-6244.

37. Fernandez-Tomas $C B$, Baltimore D: Morphogenesis of poliovirus. II. Demonstration of a new intermediate, the provirion. J Virol 1973, I 2(5): I I22-II30.

38. van der Werf S, Bradley J, Wimmer E, Studier FW, Dunn J]: Synthesis of infectious poliovirus RNA by purified T7 RNA polymerase. Proc Natl Acad Sci USA 1986, 83(8):2330-2334.

39. Herold J, Andino R: Poliovirus requires a precise 5 ' end for efficient positive-strand RNA synthesis. J Virol 2000, 74( I 4):6394-6400.

40. Teterina NL, Rinaudo MS, Ehrenfeld E: Strand-specific RNA synthesis defects in a poliovirus with a mutation in 3A. J Virol 2003, 77(23): |2679-1269|.

4I. Teterina NL, Zhou WD, Cho MW, Ehrenfeld E: Inefficient complementation activity of poliovirus $2 C$ and $3 D$ proteins for rescue of lethal mutations. J Virol 1995, 69(7):4245-4254

42. Egger D, Teterina N, Ehrenfeld E, Bienz K: Formation of the poliovirus replication complex requires coupled viral translation, vesicle production and viral RNA synthesis. I Virol 2000, 74(14):6570-6580.

43. Novak JE, Kirkegaard K: Coupling between genome translation and replication in an RNA virus. Genes and Dev 1994 8(14): | $726-1737$.
44. Xiang W, Harris KS, Alexander L, Wimmer E: Interaction between the $5^{\prime}$-terminal cloverleaf and $3 A B / 3 C D$ pro of poliovirus is essential for RNA replication. J Virol 1995, 69(6):3658-3667.

45. Rieder E, Paul AV, Kim DW, Van Boom JH, Wimmer E: Genetic and biochemical studies of poliovirus cis-acting replication element cre in relation to VPg uridylylation. J Virol 2000 , 74(22): $1037 \mid-10380$

46. Lyons T, Murray KE, Roberts AW, Barton DJ: Poliovirus 5'-terminal cloverleaf RNA is required in cis for VPg uridylylation and the initiation of negative-strand RNA synthesis. J Virol 200I, 75(22): 10696-10708.

47. Walter BL, Parsley TB, Ehrenfeld E, Semler BL: Distinct poly(rC) binding protein $\mathrm{KH}$ domain determinants for poliovirus translation initation and viral RNA replication. J Virol 2002, 76(23): | 2008- | 2022

48. Mosimann SC, Cherney MM, Sia S, Plotch S, James MNG: Refined Xray crystallographic structure of the poliovirus $3 \mathrm{C}$ gene product. I Mol Biol I997, 273(5): I032-1047.

49. Basavappa R, Syed R, Flore O, Icenogle JP, Filman DJ, Hogle JM: Role and mechanism of the maturation cleavage of VPO in poliovirus assembly: Structure of the empty capsid assembly intermediate at 2.9 A resolution. Protein Science 1994 3(10): $1651-1669$

50. Cornell CT, Brunner JE, Semler BL: Differential rescue of poliovirus RNA replication functions by genetically modified RNA polymerase precursors. J Virol 2004, 78(23): |3007-| $30 \mid 8$.

5I. Xiang W, Cuconati A, Hope D, Kirkegaard K, Wimmer E: Complete protein linkage map of poliovirus $P 3$ proteins: interaction of polymerase 3Dpol with VPg and with genetic variants of $3 \mathrm{AB}$. J Virol 1998, 72(8):6732-674l.

52. Newman JFE, Brown F: Foot-and-Mouth disease virus and poliovirus particles contain proteins of the replication complex. J Virol I997, 7 I(10):7657-7662.

53. Ambros V, Baltimore D: Protein is linked to the 5' end of poliovirus RNA by a phophodiester linkage to tyrosine. J Biol Chem 1978, 253(15):5263-5266

54. Nomoto A, Kitamura N, Golini F, Wimmer E: The 5'terminal structures of poliovirion RNA and poliovirus mRNA differ only in the genome-linked protein. Proc Natl Acad Sci USA 1977 74( I 2):5345-5349.

55. Lu HH, Yang CF, Murdin AD, Klein MH, Harber JJ, Kew OM, Wimmer $\mathrm{E}$ : Mouse neurovirulence determinants of poliovirus type I strain LS-a map to the coding regions of capsid protein VP I and proteinase 2Apro. J Virol I994, 68(I I):7507-75 I5.

56. Cuconati A, Molla A, Wimmer E: Brefeldin A inhibits cell-free, de novo synthesis of poliovirus. J Virol 1998, 72(8):6456-6464.

57. Paul AV, Rieder E, Kim DW, van Boom JH, Wimmer E: Identification of an RNA hairpin in poliovirus RNA that serves as the primary template for the uridylylation of $\mathrm{VPg}$ in vitro. J Virol 2000, 74(22): $10359-10370$.

58. Pfister T, Jones KW, Wimmer E: A cysteine-rich motif in poliovirus protein 2CATPase is involved in RNA replication and binds zinc in vitro. I Virol 2000, 74(I):334-343.

Publish with Bio Med Central and every scientist can read your work free of charge

"BioMed Central will be the most significant development for disseminating the results of biomedical research in our lifetime. "

Sir Paul Nurse, Cancer Research UK

Your research papers will be:

- available free of charge to the entire biomedical community

- peer reviewed and published immediately upon acceptance

- cited in PubMed and archived on PubMed Centra

- yours - you keep the copyright 